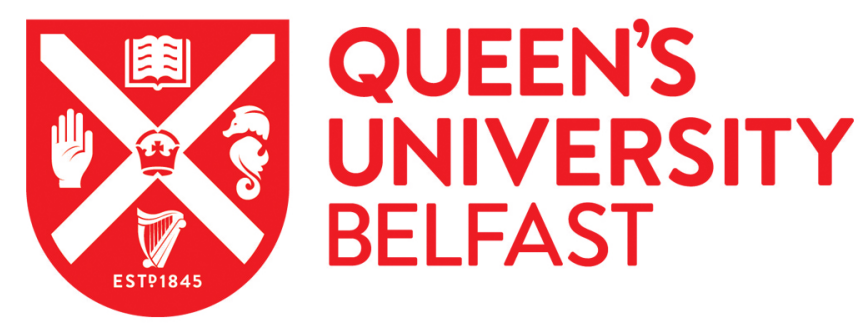

\title{
Adsorption Study using Optimised 3D Organised Mesoporous Silica Coated with Fe and Al Oxides for Specific As(III) and As(V) Removal from Contaminated Synthetic Groundwater
}

Glocheux, Y., Albadarin, A., Galán, J., Oyedoh, E., Mangwandi, C., Gérente, C., Allen, S., \& Walker, G. (2014). Adsorption Study using Optimised 3D Organised Mesoporous Silica Coated with Fe and Al Oxides for Specific As(III) and As(V) Removal from Contaminated Synthetic Groundwater. MICROPOROUS AND MESOPOROUS MATERIALS, 198, 101-114. https://doi.org/10.1016/j.micromeso.2014.07.020

Published in:

MICROPOROUS AND MESOPOROUS MATERIALS

Document Version:

Peer reviewed version

Queen's University Belfast - Research Portal:

Link to publication record in Queen's University Belfast Research Portal

\section{Publisher rights}

NOTICE: this is the author's version of a work that was accepted for publication in Microporous and Mesoporous Materials. Changes resulting from the publishing process, such as peer review, editing, corrections, structural formatting, and other quality control mechanisms may not be reflected in this document. Changes may have been made to this work since it was submitted for publication. A definitive version was subsequently published in Microporous and Mesoporous Materials, VOL198, , Nov 2014 DOI 10.1016/j.micromeso.2014.07.020

\section{General rights}

Copyright for the publications made accessible via the Queen's University Belfast Research Portal is retained by the author(s) and / or other copyright owners and it is a condition of accessing these publications that users recognise and abide by the legal requirements associated with these rights.

Take down policy

The Research Portal is Queen's institutional repository that provides access to Queen's research output. Every effort has been made to ensure that content in the Research Portal does not infringe any person's rights, or applicable UK laws. If you discover content in the

Research Portal that you believe breaches copyright or violates any law, please contact openaccess@qub.ac.uk. 


\section{Accepted Manuscript}

Adsorption Study using Optimised 3D Organised Mesoporous Silica Coated with Fe and Al Oxides for Specific As(III) and As(V) Removal from Contaminated Synthetic Groundwater

Yoann Glocheux, Ahmad B. Albadarin, José Galán, Eghe Oyedoh, Chirangano Mangwandi, Claire Gérente, Stephen J. Allen, Gavin M. Walker

PII: S1387-1811(14)00378-3

DOI: http://dx.doi.org/10.1016/j.micromeso.2014.07.020

Reference: MICMAT 6644

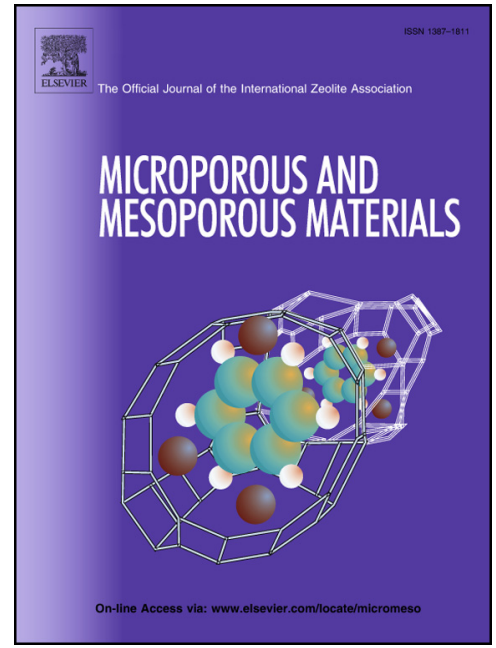

To appear in: Microporous and Mesoporous Materials

Received Date: $\quad 8$ March 2014

Revised Date: $\quad 23$ June 2014

Accepted Date: $\quad 15$ July 2014

Please cite this article as: Y. Glocheux, A.B. Albadarin, J. Galán, E. Oyedoh, C. Mangwandi, C. Gérente, S.J. Allen, G.M. Walker, Adsorption Study using Optimised 3D Organised Mesoporous Silica Coated with Fe and Al Oxides for Specific As(III) and As(V) Removal from Contaminated Synthetic Groundwater, Microporous and Mesoporous Materials (2014), doi: http://dx.doi.org/10.1016/j.micromeso.2014.07.020

This is a PDF file of an unedited manuscript that has been accepted for publication. As a service to our customers we are providing this early version of the manuscript. The manuscript will undergo copyediting, typesetting, and review of the resulting proof before it is published in its final form. Please note that during the production process errors may be discovered which could affect the content, and all legal disclaimers that apply to the journal pertain. 


\title{
Adsorption Study using Optimised 3D Organised Mesoporous
}

\section{Silica Coated with Fe and Al Oxides for Specific As(III) and As(V) Removal from Contaminated Synthetic Groundwater}

Yoann Glocheux ${ }^{1 *}$, Ahmad B. Albadarin ${ }^{1}$, José Galán ${ }^{2}$, Eghe Oyedoh ${ }^{1}$, Chirangano Mangwandi $^{1}$, Claire Gérente ${ }^{3}$, Stephen J. Allen ${ }^{1}$ and Gavin M. Walker ${ }^{1,4}$

${ }^{1}$ School of Chemistry and Chemical Engineering, Queen's University Belfast, United Kingdom

${ }^{2}$ Department of Chemical Engineering, CyPS Group, Universidad Complutense de Madrid, Spain

${ }^{3}$ GEPEA, UMR 6144, CNRS, École des Mines de Nantes, L’UNAM Université, France

${ }^{4}$ Materials Surface Science Institute, Department of Chemical and Environmental Sciences, University of Limerick, Ireland

\author{
*Corresponding author \\ Dr Yoann Glocheux \\ Tel: +44 (0) 2890974253 \\ Fax: +44 (0) 2890974627 \\ E-mail: yglocheux01@qub.ac.uk
}




\section{Abstract:}

This work presents the possibility of optimising 3D Organised Mesoporous Silica (OMS) coated with both iron and aluminium oxides for the optimal removal of As(III) and As(V) from synthetic contaminated water. The materials developed were fully characterised and were tested for removing arsenic in batch experiments. The effect of total $\mathrm{Al}$ to $\mathrm{Fe}$ oxides coating on the selective removal of $\mathrm{As}(\mathrm{III})$ and $\mathrm{As}(\mathrm{V})$ was studied. It was shown that $8 \%$ metal coating was the optimal configuration for the coated OMS materials in removing arsenic. The effect of arsenic initial concentration and $\mathrm{pH}$, kinetics and diffusion mechanisms was studied, modelled and discussed. It was shown that the advantage of an organised material over an un-structured sorbent was very limited in terms of kinetic and diffusion under the experimental conditions. It was shown that physisorption was the main adsorption process involved in As removal by the coated OMS. Maximum adsorption capacity of $55 \mathrm{mg}$ $\mathrm{As}(\mathrm{V}) \cdot \mathrm{g}^{-1}$ was noticed at $\mathrm{pH} 5$ for material coated with $8 \%$ Al oxides while $35 \mathrm{mg}$ As(V). $\mathrm{g}^{-1}$ was removed at $\mathrm{pH} 4$ for equivalent material coated with Fe oxides.

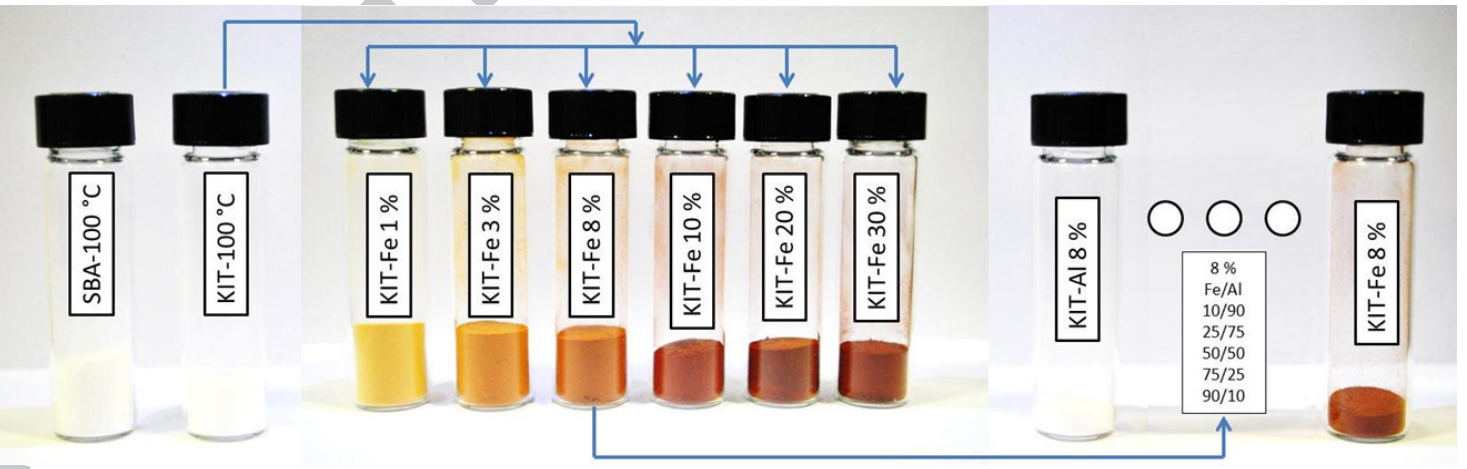




\section{Highlights:}

- 3D and 2D Organised Mesoporous Silica were efficiently coated with different Al to Fe oxides ratio

- $8 \%$ metal oxide loading was estimated to be the most appropriate content for efficient As removal

- Successful tailoring of adsorbent toward specific As(III) to As(V) ratio by varying Al to Fe oxide content was confirmed

- Tailoring of the adsorbents produced is highly dependent on the $\mathrm{pH}$ of the water treated as well as the level of contaminant concentration

- No superior diffusion of pollutants into organised materials over unorganised materials was demonstrated

Keywords: Organised Mesoporous Silica, iron oxide, aluminium oxide, arsenic removal, diffusion 


\section{Introduction}

Arsenic contamination is a problem affecting all countries throughout the world. However the countries in south and south-east Asia are considered the most vulnerable places facing this crisis which might impact many lives in the coming years [1]. The drinking water guideline from the World Health Organisation for arsenic levels was lowered to $10 \mathrm{ppb}$ in 1993 [2]. Since then, many governments have modified their legislation to adopt this guideline value as a national standard. Nevertheless, a few countries, which are facing severe arsenic contamination are still using the previous value of $50 \mathrm{ppb}$, Bangladesh being one of them $[1,3]$. The adsorption technology has been extensively used to remove toxics from water because of its low running costs, low maintenance demand and the effectiveness of the process to guarantee a good drinking water quality $[4,5]$. The different types of materials used for arsenic removal can be divided into three major categories: organic or natural ore, industrial by-product and man-made sorbents mainly relying on metal oxides. The optimisation of material removal capacity relies very often on the increase of adsorbent surface area and pore volume, the doping of materials with oxide with specific affinity toward As, or, the addition of specific chemical surface groups for either chemisorption or ion-exchange of dissolved ions [6,7]. The use of nano-sized metal oxides such as Organised Mesoporous Silica has been regarded as a major technique is enhancing pollutant removal [8]. OMS materials are very versatile materials, easy to tailor and adapt to any specific pollutant. The development of OMS was first reported by researchers at the Mobil Oil Corporation [9]. Since then, many researchers have worked on the application of organised materials mainly for catalysis, air treatment and water treatment applications [10]. Organised mesoporous silicas are interesting materials due to their high surface area, narrow pore size distribution range and high porosity [11]. The most interesting feature of OMS is the 
possibility to control, to a certain extent, most of its physical characteristics: mean pore size, porosity and surface area. OMS are useful materials as they can be a support matrix for many doping of interest. The addition of metal oxides in OMS is largely reported, mainly for its use in catalytic reactions [12] and [13] and in the removal of specific pollutant [14]. Production of mesoporous carbon can also be prepared using OMS as a template [14] and these materials have been successfully applied as adsorbents for water pollution control [15]. The same idea can be applied in order to create mesoporous metal oxides [16].

Previously, the potential for optimising the As adsorption capacity of coated OMS has been briefly presented [17]. In this current work a comprehensive and full detailed study is presented, covering both the production of the coated OMS sorbents and the impact on the As adsorption characteristics of these materials.

$\mathrm{Li}$ reported a coating process for iron oxides loading onto OMS for enhanced As(V) adsorption. Li showed that a layer by layer coating process was an efficient technique for iron loading into OMS in regards to $\mathrm{As}(\mathrm{V})$ adsorption [18].

Other studies reported innovative technics to load iron oxides into Organised Mesoporous Carbon (OMC), aluminium oxides into OMS or the direct production of Organised Mesoporous Iron oxides and their used in removing arsenic or fluoride [19-22]. The removal capacities reported were in the range of 0.16 to $4.1 \mathrm{mg} \cdot \mathrm{g}^{-1}$ for $\mathrm{As}(\mathrm{V}), 4.0$ to $7.3 \mathrm{mg} \cdot \mathrm{g}^{-1}$ for As(III) and $75.1 \mathrm{mg} \cdot \mathrm{g}^{-1}$ for $\mathrm{F}^{-}$.

The originality of the present work relies onto the possibility of tailoring an adsorbent to match a specific groundwater contaminated by a pollutant present under two different oxidation stages, namely $\mathrm{As}(\mathrm{V})$ and As(III). Different ratio of iron and aluminium oxides were coated onto the 2D and 3D OMS materials and used to control the selectivity of the adsorbents for potential arsenic removal. The chemical and physical properties of the coated $\mathrm{Al}$ and Fe oxides OMS are fully characterised and discussed. Moreover adsorption of both 5 
$\mathrm{As}(\mathrm{III})$ and $\mathrm{As}(\mathrm{V})$ are fully investigated, the effect of $\mathrm{pH}$, the kinetic and diffusion of the As species into these materials are compared. Finally, the benefit of using organised materials over unorganised materials both in terms of adsorption removal capacity and diffusion or kinetic is discussed. The unorganised iron and aluminium oxides used as references were produced under the same synthesis conditions.

\section{Materials and methods}

\subsection{Synthesis of 2D and 3D-Organised mesoporous silica coated with Fe and Al oxides}

Organised Mesoporous Silica, KIT-6 (3D organised) and SBA-15 (2D organised) were produced using a modified method presented by Rumplecker and previously reported [17,23]. Briefly, for the production of SBA-15, a solution of $252 \mathrm{~g}$ of deionised water and $7.7 \mathrm{~g}$ of $\mathrm{HCl}$ at $37 \%$ was used to dissolve $13.9 \mathrm{~g}$ of Pluronic P123. After dissolution of the surfactant, $25.0 \mathrm{~g}$ of TEOS was added. The solution was stirred in Duclan glass bottles for $24 \mathrm{~h}$ at $35^{\circ} \mathrm{C}$ using a silicon oil bath. The bottles were then placed in an autoclave to undergo a hydrothermal treatment (at $40^{\circ} \mathrm{C}, 60^{\circ} \mathrm{C}, 80^{\circ} \mathrm{C}$ or $100{ }^{\circ} \mathrm{C}$ ) for $24 \mathrm{~h}$ under static conditions. The solid product was then filtered without any washing and dried for $48 \mathrm{~h}$ at $95{ }^{\circ} \mathrm{C}$ in an oven. The surfactant was removed by calcination in flow of air at $550{ }^{\circ} \mathrm{C}$ for $6 \mathrm{~h}$ with a temperature ramp of $1{ }^{\circ} \mathrm{C} \cdot \mathrm{min}^{-1}$ and a flow of air set at $100 \mathrm{~mL} \cdot \mathrm{min}^{-1}$. Similar steps were followed to produce the KIT-6 materials with some alterations: $9.0 \mathrm{~g}$ of P123, $325 \mathrm{~g}$ of deionised water and $17.4 \mathrm{~g} \mathrm{HCl}$ were used. After complete dissolution of the surfactant, $9.0 \mathrm{~g}$ of butanol was added. Further steps were the same as for SBA-15 synthesis except the drying time which was reduced to $24 \mathrm{~h}$. Mesoporous silica were named $\mathrm{KIT}-\mathrm{XX}{ }^{\circ} \mathrm{C}$ and SBA-XX ${ }^{\circ} \mathrm{C}$ where $\mathrm{XX}$ is the hydrothermal temperature used in the synthesis. The 3D-organised mesoporous silica $\mathrm{KIT}-100{ }^{\circ} \mathrm{C}$ was selected for aluminium and iron doping because of its higher mesoporosity. This process was carried out using a solvent evaporation method; $0.8 \mathrm{M}$ 6 
aluminium and iron nitrate in absolute ethanol solutions were used to coat the mesoporous silica. Different loading percentage were studied: $1 \%$ to $8 \%$ in one impregnation step and 15 $\%$ to $30 \%$ in three impregnation steps. The percentage loading is based on the internal pores filling by $\mathrm{Al}_{2} \mathrm{O}_{3}$ or $\mathrm{Fe}_{2} \mathrm{O}_{3}$. The selected amount of iron or aluminium solution was added at once onto the mesoporous silica and was left under stirring for $1 \mathrm{~h}$. After homogeneous dispersion of the solution, the HDPE bottles were placed in an oven at $60{ }^{\circ} \mathrm{C}$ to undergo solvent evaporation. The resulting powder was then calcined at $210{ }^{\circ} \mathrm{C}$ or $250{ }^{\circ} \mathrm{C}$ into a chamber furnace to eliminate the nitrate salts following the reactions presented in Equation (1) and (2). Nitrate is usually decomposed into $\mathrm{NO}_{2}, \mathrm{NO}, \mathrm{NO}_{2}$ and $\mathrm{NO}_{3}{ }^{2-}$ for clarity reason the nitrogen species were reported as $\mathrm{N}_{2}$ [24]. Coated mesoporous silica were named KIT-YY $\mathrm{ZZ} \%$ where $\mathrm{ZZ}$ is the percentage of coating and $\mathrm{YY}$ the corresponding metal salt ( $\mathrm{Al}$ or $\mathrm{Fe}$ ).

$$
\begin{gathered}
\mathrm{Fe}\left(\mathrm{NO}_{3}\right)_{3} .9 \mathrm{H}_{2} \mathrm{O} \stackrel{210{ }^{\circ} \mathrm{C}}{\longrightarrow} 0.5 \mathrm{Fe}_{2} \mathrm{O}_{3}+1.5 \mathrm{~N}_{2}+3.75 \mathrm{O}_{2}+9 \mathrm{H}_{2} \mathrm{O} \\
\mathrm{Al}\left(\mathrm{NO}_{3}\right)_{3} .9 \mathrm{H}_{2} \mathrm{O} \stackrel{2500^{\circ} \mathrm{C}}{\longrightarrow} 0.5 \mathrm{Al}_{2} \mathrm{O}_{3}+1.5 \mathrm{~N}_{2}+3.75 \mathrm{O}_{2}+9 \mathrm{H}_{2} \mathrm{O}
\end{gathered}
$$

A set of mixed iron and aluminium coated mesoporous KIT-100 ${ }^{\circ} \mathrm{C}$ was produced by varying the relative percentage of iron and aluminium while keeping constant the total metal loading percentage at $8 \%$. The same coating procedure as for single metal oxide coating was followed. Mixed metal coated mesoporous silicas were named KIT-8 \%-Fe/Al-AA/BB where $\mathrm{AA}$ and $\mathrm{BB}$ are the iron and aluminium relative content. In order to compare the impact of the $2 \mathrm{D}$ and $3 \mathrm{D}$ organisation on the diffusion of $\mathrm{As}(\mathrm{III})$ and $\mathrm{As}(\mathrm{V})$, raw unorganised iron and aluminium oxides were produced. The synthesis procedure followed was similar to the one used for metal oxide coating.

\subsection{Adsorbents characterization}

The BET (Brunauer, Emmett and Teller) surface area, porosity and average pore size of the different materials produced were measured using a Nova 4200e Surface area and pore size 
analyser form Quantachrome Instruments. XRD (X-Ray Diffraction) analysis was carried out to first ascertain the organised structure of the OMS materials produced. The equipment used was a PANalytical X'pert model from Philips. Radiation was carried out by a $\mathrm{Cu} \mathrm{K}$-alpha 1 lamp at wavelength $0.154056 \mathrm{~nm}$. A FEI Tecnai F20 Field emission high-resolution TEM (Transmission Electron Microscopy) was used to verify the 2D and 3D organised structure of OMS and coated OMS. The TEM used had a $200 \mathrm{kV}$ accelerating voltage giving it sufficient resolution for level imaging at the nm scale. The OMS and coated OMS samples fine powder were dispersed in acetone to ensure good dispersion of the particle and limit their agglomeration. The samples were then spread onto a $\mathrm{CuO}$ grid for analysis. An EOL JSM6500F field emission SEM equipment was used for SEM-EDX (Scanning Electronic Microscope with Energy Dispersion X-Ray) analysis. Samples were analysed by FTIR (Fourier Transformation Infra-Red) using the $\mathrm{KBr}$ tableting method. A PerkinElmer Spectrum One FT-IR spectrometer instrument was used. The immersion technique was used to measure the PZC of the raw KIT material or KIT- $100{ }^{\circ} \mathrm{C}$ as well as the PZC of KIT-Fe 8 $\%$ and KIT-Al $8 \%$ materials. The procedure presented by Bourikas et al. was followed, [25]. A solid to liquid ratio of $1 \% \mathrm{w} / \mathrm{w}$ was used. The corresponding materials were weighted in $60 \mathrm{~mL}$ plastic jars and solutions of different initial $\mathrm{pH}$ having an ionic strength of $0.1 \mathrm{M} \mathrm{NaCl}$ were used. Time before equilibrium was reached was selected as $24 \mathrm{~h}$.

\section{$2.3 A s(I I I)$ and $A s(V)$ adsorption onto coated OMS experiments}

\subsubsection{Chemicals and equipment used}

The chemicals used during this work were all received from Sigma Aldrich and were all of reagent grade quality or higher. Deionised water with a resistivity of $18.2 \mathrm{M} \Omega . \mathrm{cm}$ was used in the different solutions. Appropriate amounts of $\mathrm{Na}_{2} \mathrm{HAsO}_{4} \cdot 7 \mathrm{H}_{2} \mathrm{O}$ and $\mathrm{NaAsO}_{2}$ were dissolved in deionised water to produce $\mathrm{As}(\mathrm{V})$ and $\mathrm{As}(\mathrm{III})$ stock solutions of $1000 \mathrm{ppm}$ 
respectively. $100 \mathrm{mg} . \mathrm{L}^{-1}$ of $\mathrm{NaHCO}_{3}$ was added in solutions used in adsorption experiments as a $\mathrm{pH}$ buffer. The $\mathrm{pHs}$ of all solution were adjusted using dilute solutions of $\mathrm{HCl}$ and $\mathrm{NaOH}$.

\subsubsection{Optimisation experiments}

The first set of experiments explored the effect of iron and aluminium oxides percentage loading onto the OMS. KIT materials loaded with increasing Fe or Al oxides loading percentage were used to remove As(III) or As(V). 1.0 g.L. $\mathrm{L}^{-1}$ of material was used in $50 \mathrm{~mL}$ solution of $50 \mathrm{ppm}$ of arsenic at pH 7 [17]. Solutions were stirred on a horizontal shaker for $48 \mathrm{~h}$. The second set of experiments explored the effect of co-coating Fe and Al oxides onto the OMS at different ratios and studied the potential of tuning the adsorption capacity toward the arsenic species. Arsenic adsorption experiments using $\mathrm{As}(\mathrm{III})$ and $\mathrm{As}(\mathrm{V})$ in single or binary systems were carried out. The same experimental conditions were used: 1 g.L. $\mathrm{L}^{-1}$ of adsorbent, $50 \mathrm{~mL}$ of $50 \mathrm{ppm}$ of As solution at $\mathrm{pH} 7$ in $60 \mathrm{~mL}$ glass flasks and $48 \mathrm{~h}$ experiment time on a horizontal shaker working at $100 \mathrm{rpm}$.

\subsection{3 pH effect on optimised sorbents and isotherm of adsorption}

The effect of $\mathrm{pH}$ onto As(III) and As(V) adsorption onto some selected coated OMS, KIT-Al $8 \%$ and KIT-Fe $8 \%$, were carried out in batch systems. The materials exhibited very high As removal capacity, so, initial adsorption concentration of $55 \mathrm{ppm}$ of $\mathrm{As}(\mathrm{III})$ and $\mathrm{As}(\mathrm{V})$ was used alongside a dosage ratio of $1 \mathrm{~g} . \mathrm{L}^{-1}$. Initial pHs ranging from 2 to 12 and equilibrium $\mathrm{pHs}$ were recorded by a Thermo Scientific Orion 3 Star $\mathrm{pH}$ meter equipped with a Camlab $\mathrm{pH}$ probe accurately calibrated over the study $\mathrm{pH}$ range. The isotherms of adsorption of arsenic species onto selected adsorbents were performed with initial As concentrations ranging from 1 to $50 \mathrm{ppm}$ at $\mathrm{pH} 7$. 
2.3.4 Arsenic kinetics of adsorption onto $2 D$ and $3 D$ organised mesoporous silica coated with $\mathrm{Fe}$ and $\mathrm{Al}$ oxides and raw Fe and Al oxides

The influence of organised or unorganised structured materials onto the kinetic removal of As species was tested in $1 \mathrm{~L}$ beaker containing $1 \mathrm{~L}$ solution. The adsorbent dosage was 1 g.L $\mathrm{L}^{-1}$, initial pH 7 and the magnetic stirrers used working at $300 \mathrm{rpm}$. The kinetics data points come from regularly taken samples of $5 \mathrm{~mL}$ which were diluted to $10 \mathrm{~mL}$ using deionised water. Experiments were carried out over $48 \mathrm{~h}$ with initial concentration of $50 \mathrm{ppm}$ approximately.

\subsection{Concentration Analysis}

The only dissolved element monitored in this study was arsenic and its analysis was carried out by ICP-OES. A Thermo Scientific IRIS Intrepid model was used at a working wavelength of $189.0 \mathrm{~nm}$. Before being analysed, the samples were filtered through $13 \mu \mathrm{m}$ cut off cellulose acetate filters and acidified at $2 \% \mathrm{HNO}_{3}$. Data points obtained are the average of three consecutive analyses of the same sample.

\subsection{Mathematical modelling}

\subsubsection{Isotherms models}

The equilibrium data was modelled using Langmuir and Freundlich adsorption models, under

Sigma plot 11.0 software. These models are usually represented by Equations (3) and (4) [26].

\section{Langmuir model:}

$$
q_{e}=\frac{q_{m} b_{L} C_{e}}{1+b_{L} C_{e}}
$$

Freundlich model:

$$
q_{e}=K_{F} C_{e}^{n}
$$


where $q_{e}$ is the equilibrated adsorption capacity for a given initial concentration in $\mathrm{mg} \cdot \mathrm{g}^{-1}, q_{m}$ is the maximum pollutant adsorption capacity expressed in $\mathrm{mg} \cdot \mathrm{g}^{-1}$ and $C_{e}$ is the concentration in bulk solution at equilibrium in mg. $\mathrm{L}^{-1} . b_{L}$ is the Langmuir constant in $\mathrm{L}^{\mathrm{mg}} \mathrm{g}^{-1}$ and $K_{F}$ is the Freundlich coefficient in $\mathrm{mg}^{1-\mathrm{n}} \cdot \mathrm{g}^{-1} \cdot \mathrm{L}^{\mathrm{n}} \cdot n$ is the Freundlich equation constant and is dimensionless. The separation factor $R_{\mathrm{L}}$ presented by Weber and Chakravorti is known as the separation factor and defined by equation (5) [27].

$$
R_{L}=\frac{1}{1+b_{L} C_{o}}
$$

where $C_{o}$ is the initial pollutant concentration in $\mathrm{mg} \cdot \mathrm{L}^{-1}$. This separation factor is used to characterise the nature of the adsorption with unfavourable adsorption having a $R_{L}>1,0<R_{L}$ $<1$ for favourable reaction and $R_{L}=0$ for irreversible reaction.

The Dubinin-Radushkevich (DR) isotherm is very often used to model adsorption isotherm data and determine the mean free energy of adsorption [28]. By using equation (6) and (7) the adsorption data can be modelled, while using equation (8), the mean free energy of adsorption $E$, expressed in $\mathrm{kJ} \cdot \mathrm{mol}^{-1}$ can be calculated [29].

$$
\begin{gathered}
q_{e}=q_{s} \times e^{\left(-k_{a d} \varepsilon_{R D}{ }^{2}\right)} \\
\varepsilon_{R D}=R T \ln \left(1+\frac{1}{C_{e}}\right) \\
E=\frac{1}{\sqrt{2 k_{a d}}}
\end{gathered}
$$

where $q_{s}$ is the theoretical isotherm saturation capacity calculated in mg.g ${ }^{-1}, k_{a d}$ the DR isotherm constant in $\mathrm{mol}^{2} . \mathrm{J}^{-2}$ and $\varepsilon_{\mathrm{DR}}$ is the DR isotherm variable expressed in $\mathrm{J}_{\mathrm{mol}}{ }^{-1}$.

\subsubsection{Non-linear kinetics models}

The pseudo first and pseudo second order models were applied to the kinetic experiments data obtained using Equations (9) and (10) [30,31]. 
Pseudo first order model:

$$
\ln \left[\frac{q_{e}-q_{t}}{q_{e}}\right]=-k_{1} t
$$

Pseudo second order model:

$$
\frac{1}{\left(q_{e}-q_{t}\right)}=\frac{1}{q_{e}}+k_{2} t
$$

where $q_{t}$ is the amount of pollutant adsorbed at a specific time $t$ in mg. $\mathrm{g}^{-1} ; k_{l}$ and $k_{2}$ are the pseudo-first order kinetic constant and the pseudo second order kinetic constant expressed in in $\min ^{-1}$ and in g. $\mathrm{mg}^{-1} \cdot \mathrm{min}^{-1}$, respectively.

\subsubsection{Diffusion modelling}

The diffusion models were developed to study the diffusion of adsorbate inside the adsorbents. One of the first hypotheses used in these models is that the bulk liquid diffusion is not a limiting step, which implies that stirring energy is sufficient. In this study, two different diffusion models were applied: the intraparticle diffusion model and the Boyd diffusion model. The intraparticle model links the adsorbed quantity of pollutant at a given time with the time $t$ following Equation (11), [32,33].

$$
q_{t}=k_{a i} t^{0.5}
$$

where $k_{a i}$, the intraparticle diffusion rate is a constant expressed in $\mathrm{mg} \cdot \mathrm{g}^{-1} \cdot \mathrm{h}^{-0.5}$ and $i$ represents the diffusion stage number. The plot of $q_{t}$ versus $t$ is linear when the intraparticle diffusion is the main resistance step in the experimental conditions.

The Boyd diffusion model is usually expressed by the Equation (12), [34].

$$
\frac{q_{t}}{q_{e}}=1-\left(\frac{6}{\pi^{2}}\right) \sum_{n=1}^{\infty}\left(\frac{1}{n^{2}}\right) \exp \left(-n^{2} B \times t\right)
$$


where $B$ is a coefficient expressed in $\mathrm{h}^{-1}$. Resolving equation (12) can be done using Equations (13) and (14) based on the work of Reichenberg, [35].

For $q_{t} / q_{e} \geq 0.85$

$$
B \times t=0.4977-\ln \left(1-\frac{q_{t}}{q_{e}}\right)
$$

For $q_{t} / q_{e}<0.85$

$$
B \times t=\left(\sqrt{\pi}-\sqrt{\pi-\left(\frac{\pi^{2} \frac{q_{t}}{q_{e}}}{3}\right)}\right)^{2}
$$

Using $B$ an average diffusion coefficient can be approximated using equation (15) as explained by Reichenberg, [35].

$$
B=\frac{\pi^{2} \times D_{e f f}}{r^{2}}
$$

where $r$ is the radius of the material particle. If the resulting plot of $B \times t$ versus $t$ is a straight line passing through the origin then the main resistance is based on intraparticle diffusion and $\mathrm{D}_{\text {eff }}=\mathrm{D}_{\text {intra }}$ [34]. Using an optimisation tool, the different diffusion constant were calculated for each diffusion step identified [34].

\section{Results and discussion}

\subsection{Characteristics of adsorbents samples}

\subsubsection{Surface area, pore size distribution and porosity analysis}

The pore size distributions of the uncoated KIT materials produced at different temperatures are presented in Figure 1 (a). It can be seen that the average pore diameter increases for KIT materials with an increase in the hydrothermal curing temperature. The wider average diameter obtained was evaluated at $6.4 \mathrm{~nm}$ for the KIT-100 ${ }^{\circ} \mathrm{C}$ material. In Figure 1 (b) it can 
be noted that the KIT- $100{ }^{\circ} \mathrm{C}$ displays a higher mesopores volume than the SBA-100 ${ }^{\circ} \mathrm{C}$. The increase in the $\mathrm{N}_{2}$ adsorbed volume is higher in the region of 0.6 and 0.8 relative pressure. Moreover, the steady higher increase of $\mathrm{N}_{2}$ sorbed in the region of 0.1 and 0.5 relative pressure proves that the micropore volume of $\mathrm{KIT}-100{ }^{\circ} \mathrm{C}$ is also higher than the SBA-100 ${ }^{\circ} \mathrm{C}$. Finally, the macropores volume of both materials is very limited as shown by the plateau achieved for both $\mathrm{N}_{2}$ adsorption isotherms at relative pressure between 0.8 and 1.0. It can also be noted that both isotherms follow the type IV isotherm with a sharp increase and rather wide hysteresis loop type H1 as defined by IUPAC [36]. These features are characteristic of organized mesoporous materials with a narrow pore size distribution. Due to the superior physical characteristics displayed by KIT-100 ${ }^{\circ} \mathrm{C}$ mesoporous silica, this material was then selected for iron and aluminium oxides coating.

Table 1 presents the BET analysis results of the two series of KIT- $100{ }^{\circ} \mathrm{C}$ materials coated by increasing iron or aluminium oxide content. It was found that, after $8 \%$ of the pores were filled by iron oxides, the coated OMS presented a significant loss in surface area and porosity. This same difference is noted after $3 \%$ of coating in the case of aluminium oxide coating. For samples coated by $15 \%$ of metal oxides and higher, the coating procedure was achieved in two steps which might have increased the pore blockage and might have increased the amount of remaining unoxidized nitrate groups in the pores. In the case of aluminium oxides, the high presence of remaining unoxidized nitrate groups is clearly responsible for the early pore filling. The presence of remaining nitrate groups was identified by FTIR analysis and is discussed below.

Table 2 summarises the physical characteristics of the materials used in different adsorption experiments. The BET analysis measured a very low surface area and porosity for the Al oxide sample. The very low measurement obtained can be accounted for by the release of species from the remaining nitrate or an obstruction of the pores by nitrate molecules. Al 14 
oxides produced using conventional sol-gel method usually display surface area in the region of $200 \mathrm{~m}^{2} \cdot \mathrm{g}^{-1}$ and porosity around $0.4 \mathrm{cc} \cdot \mathrm{g}^{-1}$ [37].

\subsubsection{XRD analysis: organised structure of material and coating identification}

The amorphous nature of SBA-15 and KIT-6 materials produced at $100{ }^{\circ} \mathrm{C}$ was confirmed as no silica oxides crystal was identified, as no major peaks were identified at high diffraction angle, see Figure 2 (a). The XRD spectrum of both materials show the organised nature of their respective structure as indicated by the low angle peaks noticed at $0.7^{\circ}$ and $1.1^{\circ}$ respectively (Figure 2 (b)). These peaks are characteristic of organised mesoporous materials and are always reported in this region [38] and [39]. The XRD analysis on the coated OMS did not allow a clear identification of the iron and aluminium oxides coated on the surface, probably due to the fact that most of oxides were present inside the pores. Iron oxides were identified as Hematite, while aluminium oxides could not be specifically identified as seen in Figure 3, even if Boehmite is the most probable crystal formed.

\subsubsection{TEM imaging analysis}

Figure 4 (a) and (d) presents the 3D organised KIT-6 structure and Figure 4 (b) and (e) the 2D organised structure of SBA-15. It is difficult to clearly identify the 3D organised pattern but the 2D pattern is clearly visible in both directions in Figure 4 (b). Coating SBA-15 internal walls with iron oxide appears to lead to particles growth in-homogeneously distributed into the pores, as seen in Figure 4 (e) and (f). The coating process is in reality closer to particle growth inside the pores rather than an homogeneous coating, as some gaps can be spotted inside the pores, Figure 4 (f). There was no oxide growth noticed outside the pores for SBA-Fe $8 \%$, KIT-Fe $8 \%$, SBA-Al $8 \%$ or KIT-Al $8 \%$ materials.

\subsubsection{FTIR analysis: chemical surface groups identification}

SBA- $100{ }^{\circ} \mathrm{C}$ and $\mathrm{KIT}-100{ }^{\circ} \mathrm{C}$ were analysed by FTIR prior to coating by iron and aluminium oxides. KIT-Fe $8 \%$ and KIT-Al $8 \%$ were studied by FTIR before and after adsorption by 15 
As(III) and As(V) of $50 \mathrm{ppm}$ at $\mathrm{pH}$. The FTIR analysis of $\mathrm{KIT}-100{ }^{\circ} \mathrm{C}$ and SBA-100 ${ }^{\circ} \mathrm{C}$ is presented in Figure 5 (a) while KIT-100 ${ }^{\circ} \mathrm{C}$, KIT-Fe $8 \%$ and KIT-Al $8 \%$ are shown in Figure 5 (b). The peak at $1635 \mathrm{~cm}^{-1}$ indicates the presence of free water molecules and bonded water molecules onto the two silica samples. The broad peak at $3430 \mathrm{~cm}^{-1}$ is attributed to the $\mathrm{O}-\mathrm{H}$ stretching bonds. In the present case, this peak comes from the water molecules bonded onto the silica since all hydroxyl $\left(\mathrm{OH}^{-}\right)$groups from silanol $(\mathrm{Si}-\mathrm{O}-\mathrm{H})$ groups have been removed during the calcination process at $800{ }^{\circ} \mathrm{C}$ [40] and [41]. The double peak at 1160 and $1070 \mathrm{~cm}^{-1}$ is characteristic of $\mathrm{Si}-\mathrm{O}$ bonds as well as the peaks noticeable at $965,800 \mathrm{~cm}^{-1}$ and the one starting at $500 \mathrm{~cm}^{-1}$ [42]. There is no major difference between the two sample spectra as they are both amorphous silica. The KIT-Fe $8 \%$ spectrum shows a wider and higher peak at $3430 \mathrm{~cm}^{-1}$ revealing a higher content of $\mathrm{O}-\mathrm{H}$ bonds. These bonds come from a higher presence of bonded water, as seen with the higher peak at $1635 \mathrm{~cm}^{-1}$, and the presence of Fe-OH groups. The clear higher peak at $1170 \mathrm{~cm}^{-1}$ compared to the peak at $1070 \mathrm{~cm}^{-1}$ is characteristic of Fe-O bonds as presented by Martinez et al. [42]. The KIT-Al 8 $\%$ spectrum presents an even wider and higher peak in the region of 3500 to $3000 \mathrm{~cm}^{-1}$ revealing a very high increase in $\mathrm{O}-\mathrm{H}$ bonds. These bonds can be attributed to Al-OH surface groups. The presence of a sharp peak at $1386 \mathrm{~cm}^{-1}$ proves that $-\mathrm{NO}_{3}$ groups from the aluminium nitrate salt used during the coating process were not completely removed during the calcination step at $250{ }^{\circ} \mathrm{C}$. This peak is related to $-\mathrm{N}$ bonding and can relate to any nitrogen containing species $\left(\mathrm{N}_{2}, \mathrm{NO}, \mathrm{N}_{2} \mathrm{O}\right)$. The relative increase of the peak at $1200 \mathrm{~cm}^{-1}$ reveals the presence of Al-O bonds. The spectrum thus obtained is very similar to the one produced by Shin et al. for the adsorption of phosphate from water [43].

\subsubsection{SEM-EDX}

An EDX analysis was carried out only on KIT-Fe $8 \%$ sample in order to verify the iron coating process. The identification spectrum and the quantitative analysis of a small portion 16 
of the sample are reported in supporting information, Figure S1 and Table S1. The total iron content of the sample is quite high $(\sim 11 \%)$ on the sample area analysed. The real sample iron content is even higher when the carbon counted is removed as that is due to the carbon coating $(\sim 14.5 \%)$ in sample preparation. This value can be compared with the $8 \% \mathrm{Fe}_{2} \mathrm{O}_{3}$ content coated into the pores. This value means that $8 \%$ of the pore volume is occupied by $\mathrm{Fe}_{2} \mathrm{O}_{3}$. Using the KIT-6 BET porosity of $1.356 \mathrm{cc} \cdot \mathrm{g}^{-1}$ and assuming $\mathrm{Fe}_{2} \mathrm{O}_{3}$ density being 5.24 g.cc ${ }^{-1}$, the $8 \% \mathrm{Fe}_{2} \mathrm{O}_{3}$ pores loading results in nearly $20 \% \mathrm{Fe}$ w/w in KIT-Fe $8 \%$ as shown in equation (16).

$$
\mathrm{Fe} \% \mathrm{w} / \mathrm{w}=\mathrm{BET}_{\text {porosity }} \times \% \mathrm{Fe}_{2} \mathrm{O}_{3} \times d_{\mathrm{Fe}_{2} \mathrm{O}_{3}} \times \frac{\mathrm{M}_{\mathrm{Fe}}}{\mathrm{MFe}_{2} \mathrm{O}_{3}} \approx 20 \%
$$

The SEM-EDX analysis gives then a good approximation of the metals content $(14.5 \%$ instead of $20 \%$ ) in the coated OMS samples. The average iron content measured is slightly lower than the theoretically coated iron weight attributable to the iron oxide being coated inside the pores.

\subsection{Optimised sorbents analysis}

\subsubsection{Effect of the percentage of metal oxides coating onto As(III) and As(V) adsorption}

It was shown that, after $8 \%$ loading of iron or aluminium oxides into KIT materials, very little improvement of $\mathrm{As}(\mathrm{III})$ or $\mathrm{As}(\mathrm{V})$ was observed as shown in Figure 6. The percentage removal evolution generally followed the surface area available (Table 1). The KIT-Al material showed a very high $\mathrm{As}(\mathrm{V})$ removal capacity, while also exhibiting a very low removal capacity for As(III). In comparison, KIT-Fe materials possess a higher As(III) adsorption capability than $\mathrm{As}(\mathrm{V})$ and these two removal capacities are very close. Hence, $8 \%$ metal oxide coatings were used for subsequent optimisation experiments. This percentage coating is a good optimum balance between surface area, pore availability and arsenic removal efficiency. 


\subsubsection{Fe and Al oxide relative loading effects onto $A s(I I I)$ and $A s(V)$ removal in single and} binary solution systems

The removal of As(III) and As(V) by $8 \%$ oxides coated OMS materials having different $\mathrm{Al}$ to Fe oxides ratio is presented in Figure 7. Adsorption capacity achieved for As(III) and $\mathrm{As}(\mathrm{V})$ in single and binary systems are presented as a function of the Fe oxides percentage coating onto the $8 \%$ loaded $\mathrm{OMS}$, the $\mathrm{Al}$ oxides percentage being the remaining percentage. It was found that the arsenate adsorption capacity decreases when the Fe oxides coating content decreases, or when the Al oxides coating percentage increases. This was expected as the $\mathrm{Al}$ oxides displayed the higher $\mathrm{As}(\mathrm{V})$ adsorption capacity. The As(III) adsorption capacity was nearly constant, independently of the Al to Fe oxides coating configuration tested. The results thus show that the best coating configuration, in terms of overall adsorption capacity, i.e. $\mathrm{As}(\mathrm{III})+\mathrm{As}(\mathrm{V})$, is $10 \% \mathrm{Fe}$ oxide and $90 \% \mathrm{Al}$ oxide coating. Similar results have been reported for removal of As(III) and As(V) using iron oxide coating activated alumina [44]. The simultaneous removal of As(III) and As(V) did not show major differences, as seen in Figure 7 (b). The arsenate and total arsenic removal capacity of the coated OMS generally follow the same trend in single or binary configuration, and the As(III) and $\mathrm{As}(\mathrm{V})$ adsorption capacity are very similar in both cases. However, the materials with $\mathrm{Fe}$ oxides coating percentages between 27 to 75 display a total As removal capacity higher than the As(V) adsorption capacity in single configuration. This result shows that parts of the adsorption sites for $\mathrm{As}(\mathrm{III})$ and $\mathrm{As}(\mathrm{V})$ are different, indicating that the total removal capacity of the materials increases in binary configuration. Also, in the single As species configuration, As(III) adsorption capacity is around $6.67 \mathrm{mg} \cdot \mathrm{g}^{-1}$ and for As(V) it reaches $10.60 \mathrm{mg} \cdot \mathrm{g}^{-1}$. In the binary system, the As(V) adsorption capacity remains similar at around $10.20 \mathrm{mg} \cdot \mathrm{g}^{-1}$ and the As(III) adsorption capacity drops down to $1.37 \mathrm{mg} \cdot \mathrm{g}^{-1}$. In this case, the maximum number of As adsorption sites increases slightly, from10.60 to $11.57 \mathrm{mg} . \mathrm{g}^{-1}$ with 18 
As(III) adsorption being predominantly favoured. In the case of low Fe oxide coatings percentage i.e. $<50 \%$, the $\mathrm{As}(\mathrm{V})$ adsorption is generally favoured over $\mathrm{As}(\mathrm{III})$ adsorption in terms of total arsenic removal. It was easier to tailor the coated OMS materials toward As(V) than $\mathrm{As}(\mathrm{III})$ due to the superior As(V) adsorption capacity of Al oxide coatings. The results demonstrated the ability to tailor one material capacity toward the characteristics of a specific groundwater. Nevertheless, the possibility of optimising the coated OMS materials is limited by the maximum adsorption capacity of the pure single metal oxides and cannot cover the full range of groundwater $\mathrm{As}(\mathrm{III})$ to $\mathrm{As}(\mathrm{V})$ ratio range, i.e. $\mathrm{As}(\mathrm{III}): \mathrm{As}(\mathrm{V})$ from $0: 1$ to $1: 0$. The range covered by the optimisation technique presented in this paper for $\operatorname{As}(\mathrm{III}): \operatorname{As}(\mathrm{V})$ is $0.16: 0.84$ to $0.97: 0.13$ and is presented in detail in Table 3 .

\section{3 pH effect analysis}

The pH study of As(III) and As(V) adsorption onto KIT-Al $8 \%$ and KIT-Fe $8 \%$ is presented in Figure 8. It was found that only KIT-Al-8\% was able to remove completely As(V) at around $\mathrm{pH} 5$ and $55 \mathrm{ppm}$. The profiles of $\mathrm{As}(\mathrm{V})$ adsorption capacity in function of $\mathrm{pH}$ of KIT-Al $8 \%$ and KIT-Fe $8 \%$ have similar trends but seem to be shifted by $1 \mathrm{pH}$ value. The PZC of KIT-Al $8 \%$ and KIT-Fe $8 \%$ were evaluated at pH 5.4 and 4.5 respectively. The higher PZC of aluminium coated KIT material is partly responsible for the better performance of KIT-Al $8 \%$ in removing $\mathrm{As}(\mathrm{V})$ at neutral $\mathrm{pH}$ when compared to KIT-Fe $8 \%$ material. As(III) removal is not influenced by $\mathrm{pH}$ change until $\mathrm{pH}$, when arsenite ions start to be negatively charged $\left(\mathrm{pK}_{\mathrm{a}} \sim 9.2\right)$ and both materials become negatively charged as well $(\mathrm{pH}>\mathrm{PZC})$. It is noticed that the As(III) removal capacity of KIT-Fe $8 \%$ is better than its As(V) removal capacity only at high $\mathrm{pH}$. At $\mathrm{pH}$ between 7 and 9, KIT-Al $8 \%$ has better As(V) than As(III) removal capacity while, at the same $\mathrm{pH}$ range, KIT-Fe $8 \%$ As removal 
capacity are inversed. This $\mathrm{pH}$ study thus reveals that it is only possible to tailor the As(III) to As $(\mathrm{V})$ removal ratio of the coated OMS for As removal at $\mathrm{pH}$ between 7 and 9.

\subsection{Concentration effect analysis}

Figure 9 illustrates the isotherms of $\mathrm{As}(\mathrm{III})$ and $\mathrm{As}(\mathrm{V})$ adsorption onto KIT-Fe $8 \%$ and KITAl $8 \%$. The As(III) is removed more efficiently by KIT-Fe $8 \%$ than by KIT-Al $8 \%$ while the opposite trend is displayed for $\mathrm{As}(\mathrm{V})$ removal. As(III) isotherm is closer to a Freundlich type isotherm than a Langmuir type for As(III) removal while it is the opposite case for $\mathrm{As}(\mathrm{V})$ isotherms as per the respective $\mathrm{r}^{2}$ values from Table 4. The isotherm shape of As(III) removal by KIT-Al $8 \%$ shows the very unfavourable nature of the adsorption process involved. The values reported in Table 4 for $q_{m}$ for As(III) removal are very high but the related $b_{L}$ value is very low. This combination gives a very slow increase of the $q_{e}$ value at low concentration but implies a continuous increase until reaching a $q_{m}$ value of nearly 81 $\mathrm{mg} \cdot \mathrm{g}^{-1}$. Arsenic removal efficiency of coated OMS materials at low concentration is very low, especially for arsenite adsorption as presented by $q_{e}$ values at $0.1 \mathrm{ppm}\left(\mathrm{q}_{\mathrm{e}}-0.1\right)$. Moreover, only $\mathrm{As}(\mathrm{V})$ adsorption onto KIT-Al $8 \%$ is a relatively favourable process as the $R_{\mathrm{L}}-0.1$ value is lower than 0.8 . It is worth mentioning that the $\mathrm{As}(\mathrm{III})$ adsorption capacity of KIT-Fe $8 \%$ is higher than KIT-A1 $8 \%$ especially at high concentration and this difference decreases at low concentration as seen in Table 5. The tests performed in order to modify the coated OMS materials for specific adsorption are then very dependent on the concentration range used in the test. The optimisation study was carried out at a very high initial concentration $(\sim 50$ ppm).

Table 6 gives a comparison of the observed materials removal capacity with data from the literature for equivalent materials having high surface area and high porosity. The Fe and Al 
coated OMS materials developed in this work display high $\mathrm{As}(\mathrm{III})$ and $\mathrm{As}(\mathrm{V})$ removal capacities which are generally higher than equivalent coated mesoporous silica materials.

\subsection{Kinetic removal of arsenic in $2 D, 3 D$ and unorganised sorbents}

Figure 10 presents the kinetic removal of arsenite by unorganised, 2D and 3D organised materials coated by iron (a) or aluminium oxides (b) and the kinetic removal of arsenate by the same materials in Figure 10 (c) and (d) respectively. From Figure 10 (a), the As(III) removal by $\mathrm{Al}$ oxides is very limited compared to the removal by Fe oxides (Figure 10 (b)). The As(III) removal by KIT-Al $8 \%$ is higher than that of pure $\mathrm{Al}$ oxide at equilibrium which is in opposition to the total weigh of aluminium oxide present in each sample. When $\mathrm{Fe}$ oxides are used, the unorganised Fe materials display a higher capacity than the organised 3D material which itself present a higher capacity than the 2D organised material. The As(III) removal capacity at equilibrium of the Fe oxide material can actually be related to the total iron oxide content by weight of the materials: Fe oxide (100\%), KIT-Fe $8 \%$ (20\%), SBA-Fe $8 \%(15.4 \%)$

The As(V) removal presents very similar trends as seen in Figure 10 (c) and (d). The main difference is the much higher removal capacity of the Al oxides materials when compared to the Fe oxides materials. It was also noticed that the KIT-Al $8 \%$ material has a higher removal capacity than the unorganised Al-oxides. The Fe oxide materials show a very high removal capacity for the unorganised materials when compared to the $2 \mathrm{D}$ and $3 \mathrm{D}$ organised materials, a difference that can be again linked to the total weight of iron oxides in the materials.

In terms of removal kinetic, minor differences can be noticed, but the differences of $q e$ reached make the comparison difficult. Relative kinetic curves are thus presented in Figure 11. In Figure 11 (a) a small difference in removing As(III) by Al oxides materials being 
organised or not was found, while in Figure 11 (b) differences are visible. The kinetic performances of the iron oxides based materials toward As(III) follow the trend: unorganised $>2 \mathrm{D}>3 \mathrm{D}$. In the case of $\mathrm{As}(\mathrm{V})$ removal, little effect of the organisation of Fe oxides materials is noticed (Figure $11(\mathrm{c})$ ) while diffusion of $\mathrm{As}(\mathrm{V})$ in $\mathrm{Al}$ materials is affected by the organisation of the materials (Figure 11 (d)). The materials can be classified from the quickest to the slowest in removing As(III): SBA-Al $8 \%>$ KIT-Al $8 \%>$ Al-oxides. The $\mathrm{As}(\mathrm{III})$ diffusion is more affected by the pore size of Fe based materials while As(V) is more affected by the pore size of Al based materials. Generally, the organisation of the materials in term of kinetic performances has little impact on the removal of As(III) and As(V). The experiments were carried out with material of small particle size $(\varnothing<75 \mu \mathrm{m})$; in the case of bigger particle, an organised structure might have bigger impact than unorganised materials, especially because of a better access to the adsorption sites. Table 7 gives the pseudo first and pseudo second order model parameters obtained. In general the $k_{1}$ and $k_{2}$ values obtained for $\mathrm{As}(\mathrm{V})$ are higher than that obtained for $\mathrm{As}(\mathrm{III})$ removal for both $\mathrm{Fe}$ and $\mathrm{Al}$ based materials. This difference was already noticed in the various previous figures. The data obtained for the pseudo first and pseudo second order models, $k_{1}$ and $k_{2}$ values, are relatively higher than equivalent data found in the literature. For example Liu et al. found $k_{1}$ and $k_{2}$ values of $5.50 \times 10^{-4} \mathrm{~min}^{-1}$ and $8.80 \times 10^{-3} \mathrm{~g} \cdot \mathrm{mg}^{-1} \cdot \mathrm{min}^{-1}$ for $\mathrm{As}(\mathrm{III})$ and $5.33 \times 10^{-4} \mathrm{~min}^{-1}$ and $6.83 \times 10^{-4}$ g.mg ${ }^{-1} \cdot \min ^{-1}$ for $\mathrm{As}(\mathrm{V})$ removal by iron coated bamboo charcoal at starting arsenic concentration of $32 \mathrm{ppm}$ [51].

\subsection{Diffusion and adsorption investigation}

Generally, the intraparticle diffusion rate is constant over a period of time at initial condition only. In fact several regions can usually be noticed in the diffusion of pollutants in porous materials [34]. The presence of different linear regions in the plot of $q_{t}$ versus $t$ is usually 
assumed to show the predominance of the resistance to diffusion of one process over another [34]. The diffusion of As(III) and As(V) in unorganised and organised materials was studied using both the intraparticle diffusion model and the Boyd diffusion model.

\subsubsection{Intraparticle diffusion model}

Figure 12 [(a) and (b)] presents the intraparticle diffusion modelling applied to As(III) and $\mathrm{As}(\mathrm{V})$ adsorption onto unorganised $\mathrm{Al}$ oxides and $\mathrm{Al}$ oxides coated OMS while Figure $12[(\mathrm{c})$ and (d)] presents the same data obtained for Fe oxides and Fe oxides coated OMS. The same trends noticed in the kinetic experiments can be noticed for the diffusion modelling. Moreover it can be observed that $\mathrm{As}(\mathrm{III})$ and $\mathrm{As}(\mathrm{V})$ adsorption in $\mathrm{Al}$ oxides is mainly following a three-step diffusion process while the diffusion of these species in Fe oxides based materials seems to follow only a two-step diffusion process.

The intraparticle model does not follow a straight line which implies that intraparticle resistance is not the only one present or is evolving under the experimental conditions. The film diffusion cannot be limiting the arsenic adsorption as the particles are very small and the stirring speed sufficiently high. The presence of surface diffusion resistance is then an explanation for the profiles noticed. The decrease of the percentage of sorption sites available can also reduce significantly the diffusion of pollutant in the materials. In the present case it seems that, when the adsorbent coverage reaches a certain percentage, the diffusion nature changes thus decreasing significantly. As the adsorption is taking place, pore diffusion is initially the main resistance to As adsorption, but it is then replaced by surface resistance. There is no real correlation between the organisation dimension of the materials and the number of diffusion steps and/or the steepness of these steps. The intraparticle diffusion coefficients obtained are presented in Table 8.

In general, higher values were obtained for $\mathrm{As}(\mathrm{V})$ diffusion coefficients in the OMS materials studied. However, it should be noted that As(III) diffuses more quickly in Fe unorganised 23 
materials than in organised materials while the opposite trend is the case for $\mathrm{As}(\mathrm{V})$. Intraparticle diffusion seems to be the limiting step in the diffusion of $\mathrm{As}(\mathrm{III})$ and $\mathrm{As}(\mathrm{V})$ in the coated OMS materials.

\subsubsection{Boyd model}

The Boyd model plotted for the different materials studied can be found in the supporting information Figure S2. The Boyd model is not a straight line passing thought the origin, though, in most cases, the Boyd model can be approximated to a straight line. The intraparticle diffusion remains the limiting diffusion step. Intraparticle diffusion can be divided into pore diffusion, surface diffusion and surface adsorption. In the materials studied, the second segment of the Boyd model is characteristic of surface diffusion being the limiting step in the adsorption process. No clear difference can be noticed for the Boyd models applied to unorganised, 2D or 3D organised materials in terms of diffusion profile for the intraparticle model. In the case of As(III) adsorption onto Al based sorbents, the Boyd model is a straight line for all materials and the diffusion pattern is similar for all materials, (Figure S2 (a)). For $A s(V)$ adsorption with these same materials, 2D organised materials perform better, followed by 3D organised materials and unorganised materials, (Figure S2 (b)). The Fe based materials behaviour toward $\mathrm{As}(\mathrm{III})$ and $\mathrm{As}(\mathrm{V})$ adsorption is the opposite of that of Al based materials. For As(III) adsorption a clear difference can be noticed between unorganised and organised materials, while this difference is less clear for As(V) adsorption. The diffusion of $\mathrm{As}(\mathrm{III})$ and $\mathrm{As}(\mathrm{V})$ in Fe based materials follows 2 steps. This trend underlines the presence of surface diffusion being more of a resistance toward As adsorption in Fe based materials than in Al based materials. In general 2 steps are identified in the case of $2 \mathrm{D}$ or $3 \mathrm{D}$ organised materials. The presence of different steps in the diffusion of As inside the pores in the case of organised materials could reveal the presence of a resistance to diffusion due to the presence of channels and the effect of the walls onto the diffusion of the 24 
species in these materials. Surface diffusion is decreased, in organised materials due to the close presence of other adsorption sites and the effect of the wall. The resistance toward As diffusion in unorganised materials comes from the low porosity of these materials and a low accessibility of the sorption sites.

The $B$ values and associated $D_{\text {eff }}$ values obtained for the $\mathrm{As}(\mathrm{III})$ and $\mathrm{As}(\mathrm{V})$ adsorption onto the coated OMS sorbents are presented in Table S2. The difference in particle diameter explains the difference in the diffusion coefficients. The small particle size of the materials used in this study is mainly responsible for the low diffusion coefficient of As(III) and As(V) inside the unorganised and coated OMS material. The lower the $\mathrm{D}_{\text {eff }}$ values the better the diffusion. In general the diffusion coefficients obtained are higher for As(V) adsorption than for As(III) adsorption. This is in accordance with the kinetic parameters obtained, As(III) being removed more quickly by coated OMS than As(V).

\subsection{Adsorption processes mechanisms}

Figure 5 (c) presents the FTIR spectra of KIT-Al $8 \%$ materials before and after adsorption with $\mathrm{As}(\mathrm{III})$ and $\mathrm{As}(\mathrm{V})$ while Figure 5 (d) focuses onto the iron coated OMS. It can be noticed that the peak at $1390 \mathrm{~cm}^{-1}$ corresponding to the $-\mathrm{NO}_{3}$ bonds disappears after adsorption experiments. Remaining $-\mathrm{NO}_{3}$ groups dissolve in water during the adsorption experiments and can also react quickly with both $\mathrm{As}(\mathrm{III})$ and $\mathrm{As}(\mathrm{V})$ providing the possibility of chemisorption and the formation of precipitate (Al-As precipitate) at the surface or inside the pores.

The increase of the $890 \mathrm{~cm}^{-1}$ peak for As(V) adsorption shows the formation of Al-As bonds and the presence of chemisorption or ion-exchange in the removal process of As(V) by KITAl $8 \%$. In the case of As(III) adsorption, an increase in the $716 \mathrm{~cm}^{-1}$ peak is observed; this increase is also present for the $\mathrm{As}(\mathrm{V})$ treated sample. The peaks noticed for $\mathrm{As}(\mathrm{V})$ adsorption 
are in concordance with the results from Myneni et al. who noticed two peaks for $\mathrm{H}_{2} \mathrm{AsO}^{4-}$ bonding onto Ettringite at 760 and $908 \mathrm{~cm}^{-1}$ and 2 peaks for the bonding of $\mathrm{HAsO}_{4}{ }^{2-}$ at 690 and $865 \mathrm{~cm}^{-1}$ approximately [52]. As these two $\mathrm{As}(\mathrm{V})$ species are present at $\mathrm{pH} 7$ the peaks are probably an overlapping of the two species respective peaks. In the case of arsenic adsorption onto KIT-Fe $8 \%$ very little difference between the material before and after adsorption of both $\mathrm{As}(\mathrm{III})$ and $\mathrm{As}(\mathrm{V})$ can be noticed. This shows the predominance of physisorption processes over chemisorption in the removal of As by this material. The lower level of removal capacity of the material can also account for the difficulty in identifying clear peaks. Table 9 shows the DR isotherms parameters obtained for the adsorption of As(III) and As(V) onto KIT-Al $8 \%$ and KIT-Fe $8 \%$. The energy of adsorption associated with the different processes shows that physisorption is governing all these adsorption reactions $\left(\mathrm{E}<8 \mathrm{~kJ}^{\mathrm{m}} \mathrm{mol}^{-1}\right)$. Only the adsorption of As(V) by KIT-Al $8 \%$ can be associated with ion-exchange or chemisorption to some extent. This is usually observed in the literature, for example the removal of $\mathrm{As}(\mathrm{V})$ by $\mathrm{Al}$ coated mesoporous silica made from silica rice was governed by chemisorption according to Wantala et al. [53].

\section{Conclusion}

This work revealed the possibility of using specific iron and aluminium oxides coated 3D Organised Mesoporous Silica materials simultaneously in order to adsorb specific amounts of As(III) and $\mathrm{As}(\mathrm{V})$. This procedure enables the newly developed materials to perfectly match specific groundwater characteristics. The materials produced were fully characterised and tested in batch experiments, showing a very high removal capacity, around $7.38 \mathrm{mg}^{-1} \mathrm{~g}^{-1}$ for $\mathrm{As}(\mathrm{V})$ and $0.21 \mathrm{mg} \cdot \mathrm{g}^{-1}$ for $\mathrm{As}(\mathrm{III})$ at $100 \mathrm{ppb}$. The $\mathrm{pH}$ effect showed very similar behaviour of $\mathrm{As}(\mathrm{V})$ adsorption by KIT-Al $8 \%$ or KIT-Fe $8 \%$ with a maximum adsorption capacity noticed at $\mathrm{pHs}$ closed the respective materials PZC. Very significant increase of As(V) 
adsorption capacity was noticed at low $\mathrm{pH}$ : for KIT-Al $8 \%$, a maximum of $55 \mathrm{mg} \cdot \mathrm{g}^{-1}$ at $\mathrm{pH} 5$ and, for KIT-Fe $8 \%$, a maximum of $35 \mathrm{mg} \cdot \mathrm{g}^{-1}$ at $\mathrm{pH} 4$. The possibility to tailor the coating of the OMS materials toward As(III) or As(V) using both iron and aluminium oxides will then be very dependent on the groundwater $\mathrm{pH}$. Moreover the kinetic and diffusion studies demonstrated an insufficient effect of the 3D or 2D organisation structure compared to unorganised materials. Unorganised materials reached equilibrium more quickly than organised materials. Granulation of materials will be carried out to ascertain the potential higher diffusion properties of organised materials. Finally, the study showed that the main adsorption process was physisorption, with the presence of minor chemisorption mechanisms due to remaining $-\mathrm{NO}_{3}{ }^{-}$groups from unoxidized nitrate compounds.

\section{Acknowledgement}

This work was performed as part of the EU Framework 7 project "ATWARM" (Marie Curie ITN, No. 238273). The authors would like to thank QUESTOR centre staff for their technical support. 


\section{References}

[1] K. Kemper, K. Minnatullah, Towards a More Effective Operational Response - Arsenic Contamination of Groundwater in South and East Asian Countries (2/2), World Bank, Water and Sanitation Program, 2005.

[2] World Health Organization, Guidelines for Drinking-Water Quality: Recommendations, World Health Organization, 2004.

[3] D. Mohan, C.U. Pittman Jr., Journal of Hazardous Materials 142 (2007) 1.

[4] A.B. Albadarin, A.H. Al-Muhtaseb, G.M. Walker, S.J. Allen, M.N. Ahmad, Desalination 274 (2011) 64.

[5] A.B. Albadarin, C. Mangwandi, G.M. Walker, S.J. Allen, M.N. Ahmad, Chem. Eng. Trans 24 (2011) 1297.

[6] S.-G. Chung, J.-C. Ryu, M.-K. Song, B. An, S.-B. Kim, S.-H. Lee, J.-W. Choi, Journal of Hazardous Materials 267 (2014) 161.

[7] J. Torres-Perez, C. Gerente, Y. Andres, Journal of Environmental Science and Health, Part A 47 (2012) 1173.

[8] M. Hua, S. Zhang, B. Pan, W. Zhang, L. Lv, Q. Zhang, Journal of Hazardous Materials 211-212 (2012) 317.

[9] R.M. Barrer, P.J. Denny, J. Chem. Soc. (1961) 971.

[10] A. Walcarius, L. Mercier, J. Mater. Chem. 20 (2010) 4478.

[11] U. Ciesla, F. Schüth, Microporous and Mesoporous Materials 27 (1999) 131.

[12] R.M. Rioux, H. Song, J.D. Hoefelmeyer, P. Yang, G.A. Somorjai, J. Phys. Chem. B 109 (2005) 2192.

[13] H. Song, R.M. Rioux, J.D. Hoefelmeyer, R. Komor, K. Niesz, M. Grass, P. Yang, G.A. Somorjai, J. Am. Chem. Soc. 128 (2006) 3027.

[14] J. Galán, A. Rodríguez, J.M. Gómez, S.J. Allen, G.M. Walker, Chemical Engineering Journal 219 (2013) 62.

[15] Z. Wu, D. Zhao, Chemical Communications 47 (2011) 3332.

[16] H. Tüysüz, C.W. Lehmann, H. Bongard, B. Tesche, R. Schmidt, F. Schüth, J. Am. Chem. Soc. 130 (2008) 11510.

[17] Y. Glocheux, Z. Gholamvand, K. Nolan, A. Morrissey, S.J. Allen, G.M. Walker, Chemical Engineering Transactions 32 (2013).

[18] F. Li, Microporous and Mesoporous Materials 171 (2013) 139.

[19] Z. Gu, B. Deng, J. Yang, Microporous and Mesoporous Materials 102 (2007) 265.

[20] M. Jang, E.W. Shin, J.K. Park, S.I. Choi, Environ. Sci. Technol. 37 (2003) 5062.

[21] L.I. Fei-hu, F.U. Xiao-ru, H. Jie, Z. Jian-ping, L.I. Fei-hu, F.U. Xiao-ru, H. Jie, Z. Jianping, CHEMICAL RESEARCH IN CHINESE UNIVERSITES 28 (2012) 559.

[22] F. Li, H. Fu, J. Zhai, Q. Li, Microporous and Mesoporous Materials 123 (2009) 177.

[23] A. Rumplecker, Host-Guest Chemistry of Mesoscopically Ordered Porous Materials, Ruhr-Universität Bochum, Universitätsbibliothek, 2007.

[24] E. El-Shereafy, M.M. Abousekkina, A. Mashaly, M. El-Ashry, J Radioanal Nucl Chem 237 (1998) 183.

[25] K. Bourikas, J. Vakros, C. Kordulis, A. Lycourghiotis, J. Phys. Chem. B 107 (2003) 9441.

[26] G. Limousin, J.-P. Gaudet, L. Charlet, S. Szenknect, V. Barthès, M. Krimissa, Applied Geochemistry 22 (2007) 249.

[27] T.W. Weber, R.K. Chakravorti, AIChE Journal 20 (1974) 228. 
[28] A.O. Dada, A.P. Olalekan, A.M. Olatunya, O. DADA, IOSR Journal of Applied Chemistry 3 (2012) 38.

[29] N.D. Hutson, R.T. Yang, Adsorption 3 (1997) 189.

[30] S. Lagergren, Kungliga Svenska Vetenskapsakademiens Handlingar 24 (1898) 1.

[31] Y.. Ho, G. McKay, Process Biochemistry 34 (1999) 451.

[32] W.J. Weber, J.C. Morris, J. Sanit. Eng. Div. Am. Soc. Civ. Eng 89 (1963) 31.

[33] Y.S. Ho, J.C.Y. Ng, G. McKay, Separation \& Purification Reviews 29 (2000) 189.

[34] G.F. Malash, M.I. El-Khaiary, Chemical Engineering Journal 163 (2010) 256.

[35] D. Reichenberg, J. Am. Chem. Soc. 75 (1953) 589.

[36] K.S.W. Sing, D.H. Everett, R. a. W. Haul, L. Moscou, R.A. Pierotti, J. Rouquerol, T. Siemieniewska, Pure and Applied Chemistry 57 (1985) 603.

[37] A.R. Keshavarz, M. Rezaei, F. Yaripour, Powder Technology 199 (2010) 176.

[38] S. Abdollahzadeh-Ghom, C. Zamani, T. Andreu, M. Epifani, J.R. Morante, Applied Catalysis B: Environmental 108-109 (2011) 32.

[39] F. Kleitz, S. Hei Choi, R. Ryoo, Chemical Communications (2003) 2136.

[40] G. Navarra, E. Vella, S. Grandi, M. Leone, R. Boscaino, Journal of Non-Crystalline Solids 355 (2009) 1028.

[41] Z. Luan, J.A. Fournier, Microporous and Mesoporous Materials 79 (2005) 235.

[42] J.R. Martínez, F. Ruiz, Y.V. Vorobiev, F. Pérez-Robles, J. González-Hernández, The Journal of Chemical Physics 109 (1998) 7511.

[43] E.W. Shin, J.S. Han, M. Jang, S.-H. Min, J.K. Park, R.M. Rowell, Environmental Science \& Technology 38 (2004) 912.

[44] F. Azizian, Water Treatment Product and Method, 2003.

[45] P. Pillewan, S. Mukherjee, T. Roychowdhury, S. Das, A. Bansiwal, S. Rayalu, Journal of Hazardous Materials 186 (2011) 367.

[46] J.-C. Zuo, S.-R. Tong, X.-L. Yu, L.-Y. Wu, C.-Y. Cao, M.-F. Ge, W.-G. Song, Journal of Hazardous Materials 235-236 (2012) 336.

[47] T.V. Nguyen, S. Vigneswaran, H.H. Ngo, J. Kandasamy, Journal of Hazardous Materials 182 (2010) 723.

[48] W. Li, C.-Y. Cao, L.-Y. Wu, M.-F. Ge, W.-G. Song, Journal of Hazardous Materials 198 (2011) 143.

[49] H. Zhu, Y. Jia, X. Wu, H. Wang, Journal of Hazardous Materials 172 (2009) 1591.

[50] W. Xu, J. Wang, L. Wang, G. Sheng, J. Liu, H. Yu, X.-J. Huang, Journal of Hazardous Materials 260 (2013) 498.

[51] X. Liu, H. Ao, X. Xiong, J. Xiao, J. Liu, Water Air Soil Pollut 223 (2012) 1033.

[52] S.C. Myneni, S.J. Traina, G.A. Waychunas, T.J. Logan, Geochimica et Cosmochimica Acta 62 (1998) 3499.

[53] K. Wantala, S. Sthiannopkao, B. Srinameb, N. Grisdanurak, K.-W. Kim, S. Han, Journal of Environmental Engineering 138 (2012) 119. 


\section{FIGURES}
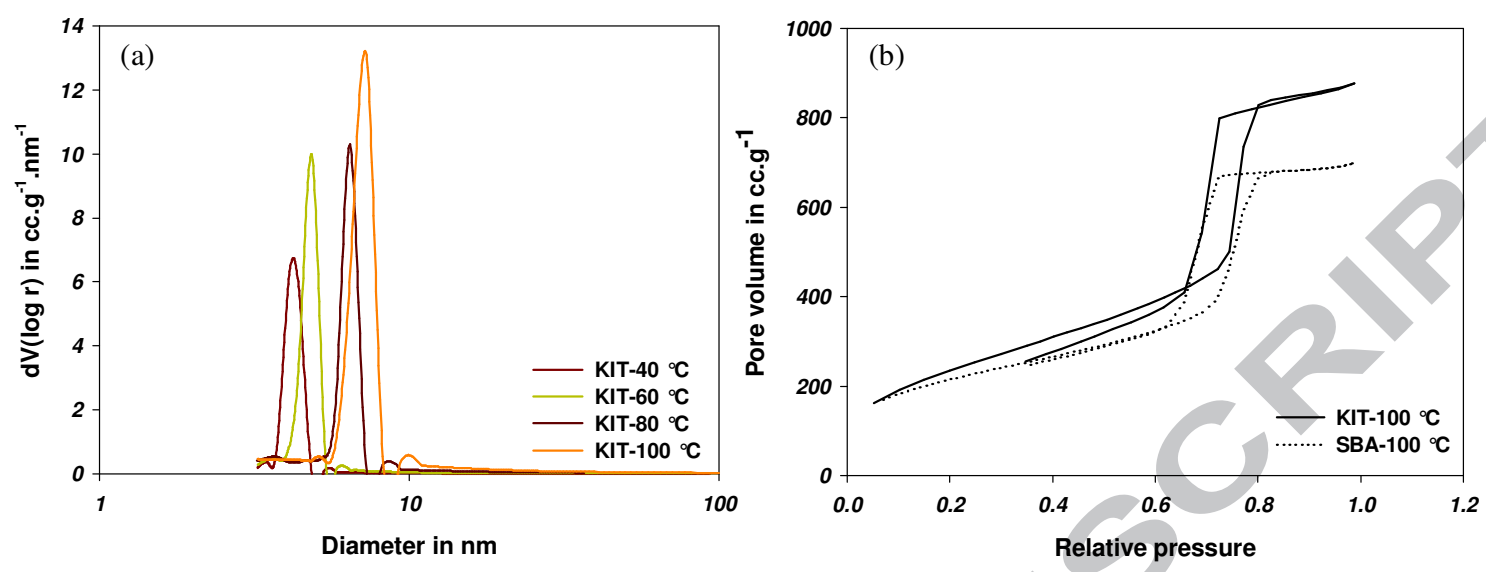

Figure 1 Pore size distribution of the KIT serie of materials produced at different temperature (a) and $\mathrm{N}_{2}$ adsorption isotherm of $\mathrm{KIT}-100{ }^{\circ} \mathrm{C}$ and $\mathrm{SBA}-100{ }^{\circ} \mathrm{C}(\mathrm{b})$
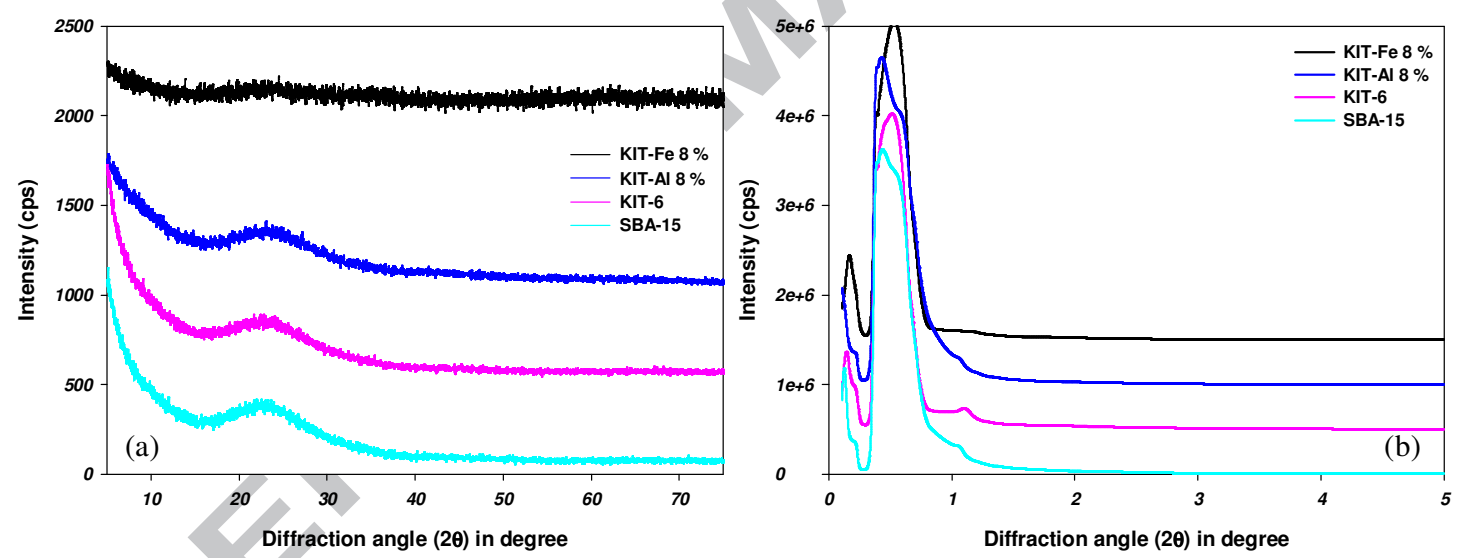

Figure 2 Full range XRD analysis ( 5 to 75 20) (a) with spectra shifted by 500 cps and low angle XRD analysis (0.1 to 5 20) (b) with spectra shifted by $5 \times 10^{5}$ cps of OMS and selected coated OMS materials 


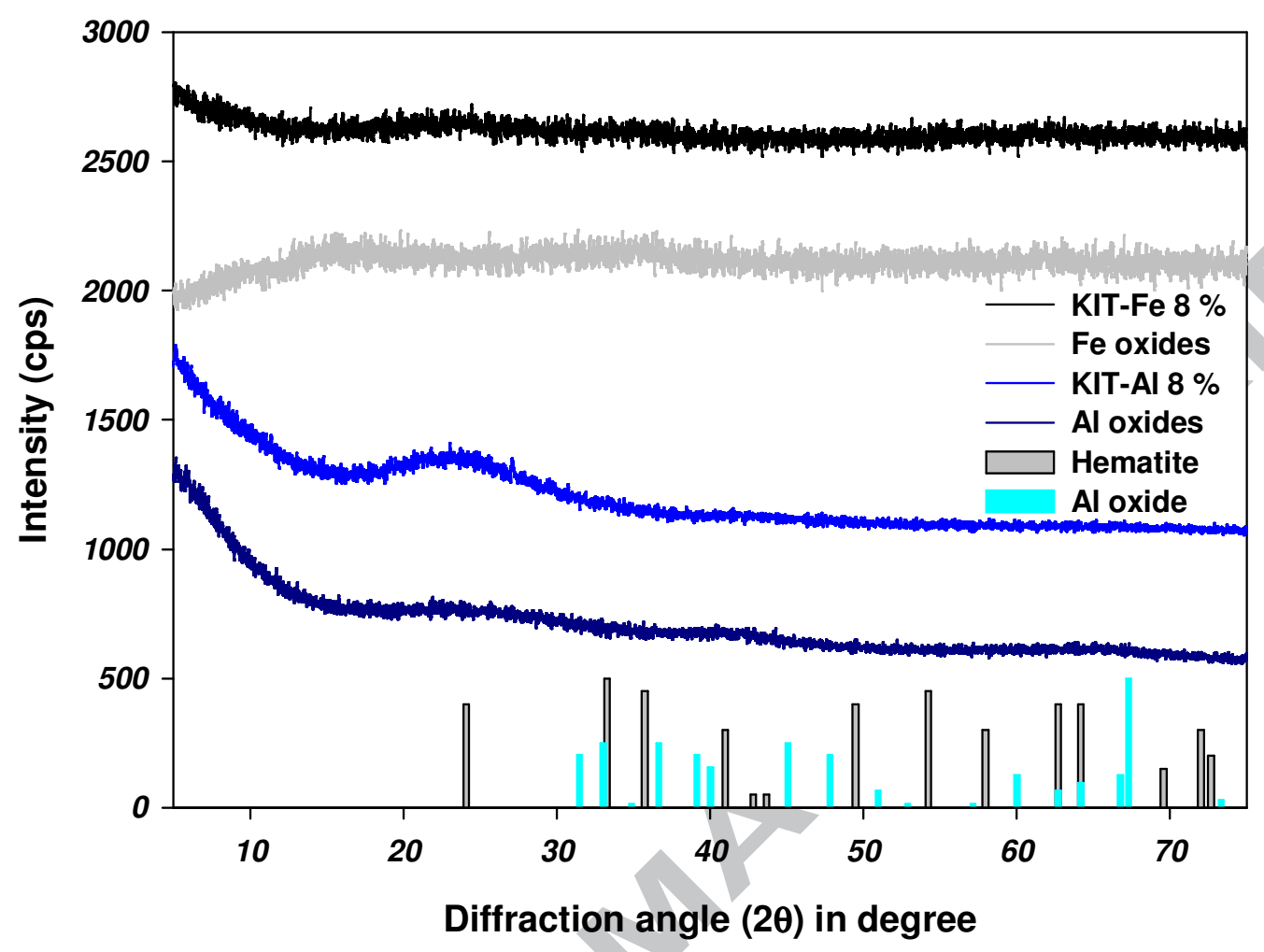

Figure 3 XRD analysis of selected coated OMS and raw oxides. Full scan (5 to 75 20) with identified Fe and Al oxides phase XRD main peaks 

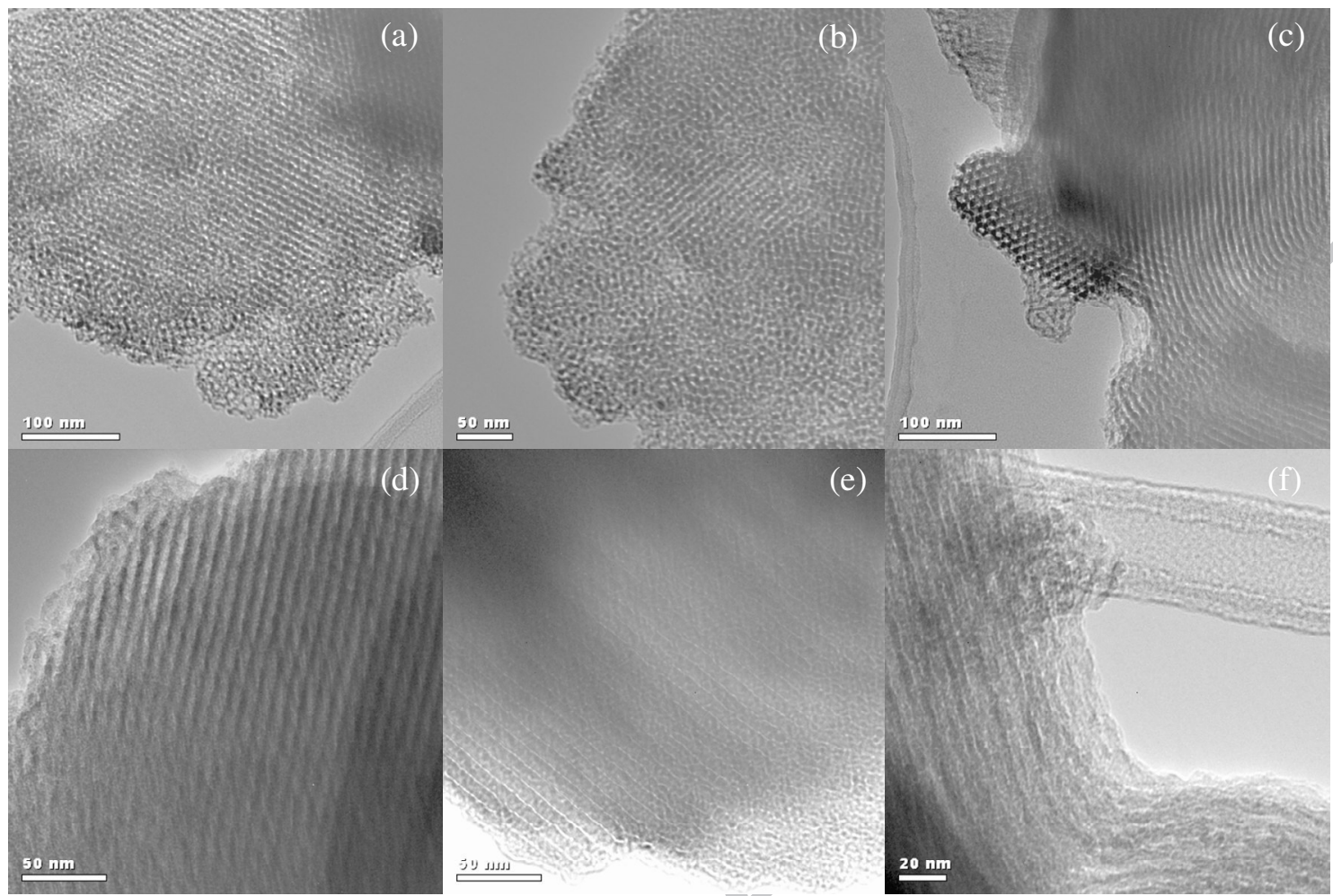

(e)

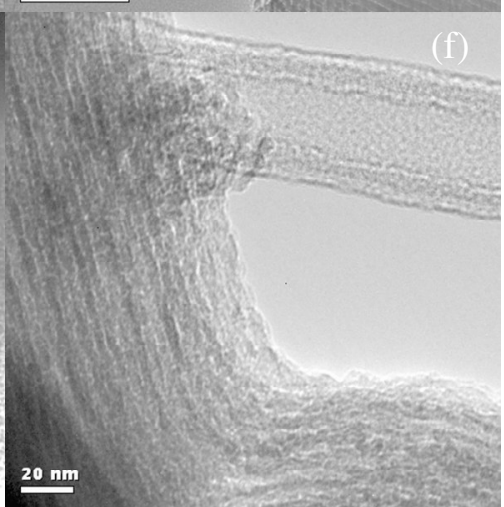

Figure 4 TEM images of selected OMS and coated OMS. KIT-100 x38000 (a) and x43000 (d), SBA-100 x38000 (b) and x71000 (e) and SBA-Fe $8 \%$ x71000 (c) and x97000 (f) 

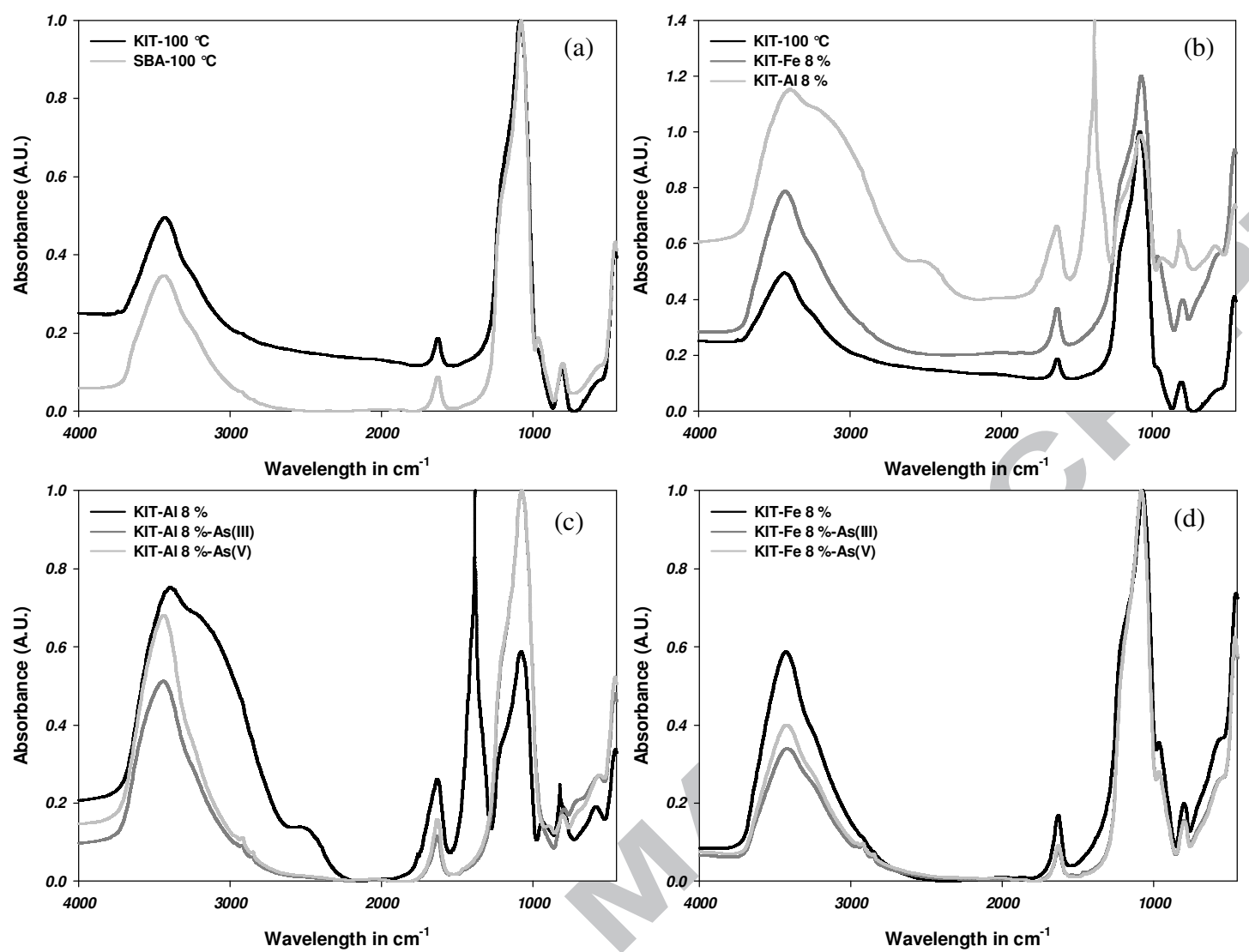

Figure 5 FTIR analysis of KIT-100 ${ }^{\circ} \mathrm{C}$ and SBA-100 ${ }^{\circ} \mathrm{C}$, spectrum un-shifted (a) and comparison of KIT-100 ${ }^{\circ} \mathrm{C}$ and KIT coated with $8 \%$ Al or $8 \% \mathrm{Fe}$, spectrum shifted by 0.2 A.U. FTIR analysis of KIT coated with $8 \%$ Al (c) or Fe (d) oxides before and after adsorption of $\mathrm{As}(\mathrm{III})$ and $\mathrm{As}(\mathrm{V})$ 

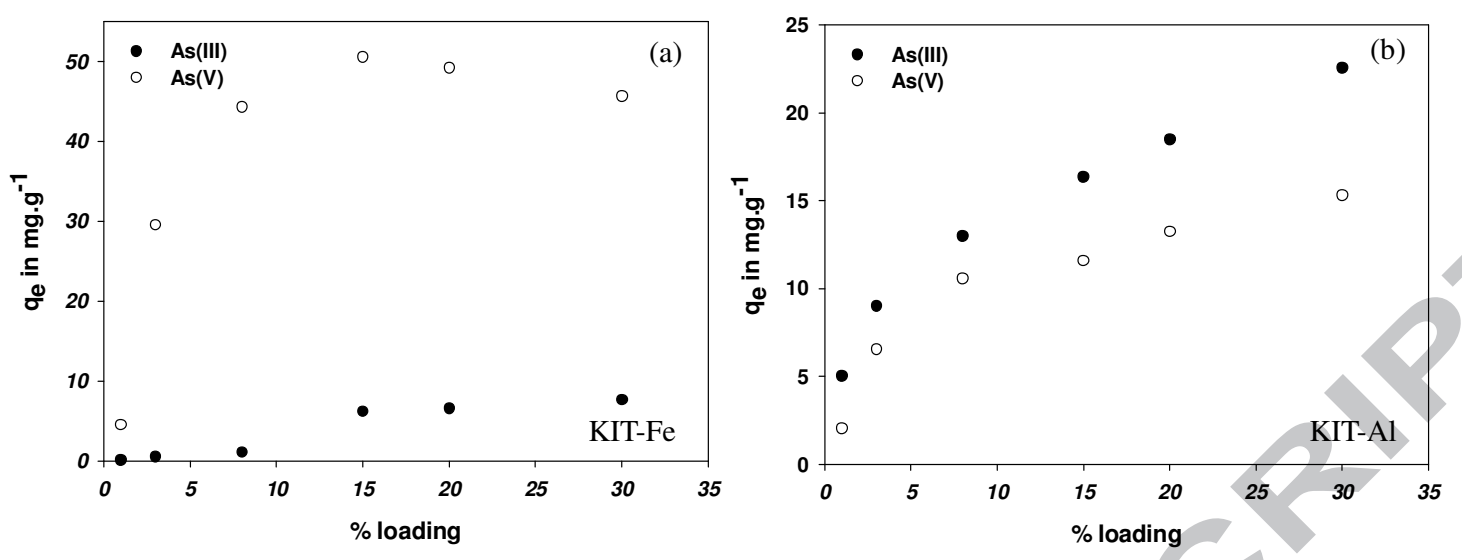

Figure 6 Arsenic adsorption onto KIT-Fe (a) and KIT-Al (b) adsorbents loaded with increasing metal oxide content (adsorbent concentration is 1 g.L $\mathrm{L}^{-1}$; initial corresponding arsenic concentration is $\sim 50 \mathrm{ppm}$ and equilibrium $\mathbf{p H}$ is

8)
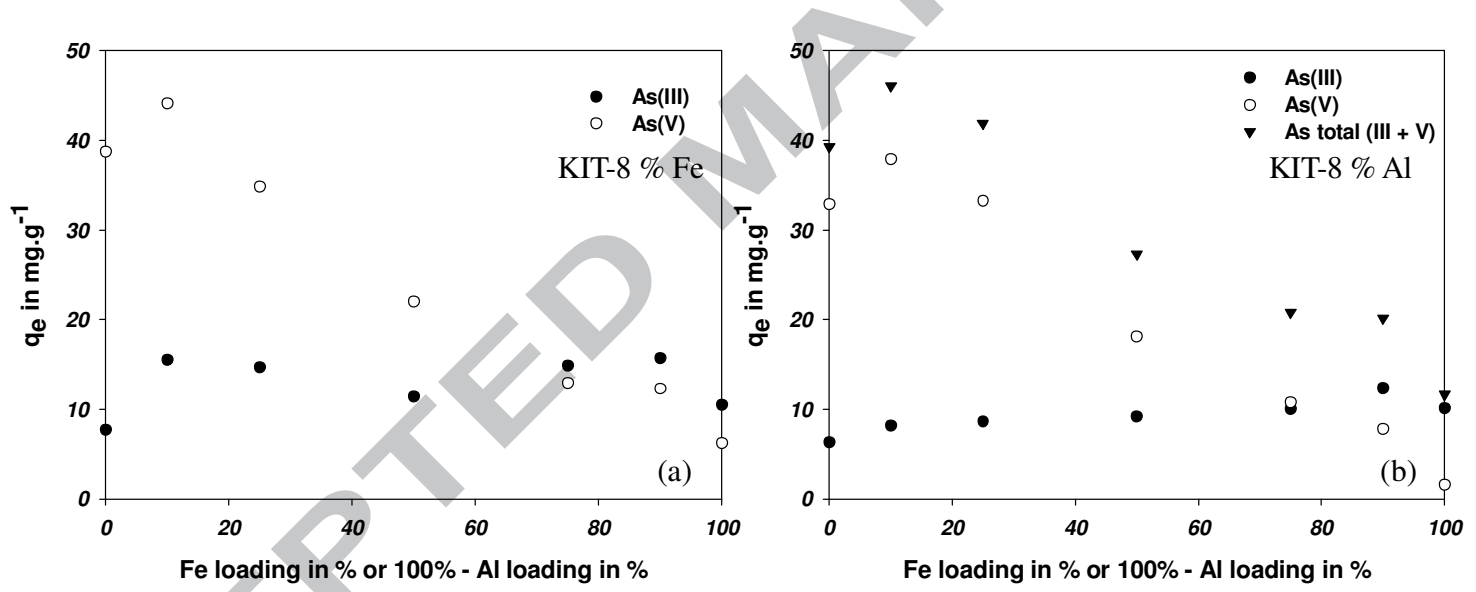

Figure 7 As(III) and As(V) single compound removal study (a) and simultaneous As(III) and As(V) removal study (b) using KIT coated with $8 \%$ mixed Al and Fe oxides (adsorbent concentration is 1 g.L ${ }^{-1}$; initial corresponding arsenic concentration is $\sim 50 \mathrm{ppm}$ and equilibrium $\mathrm{pH}$ is $\sim 8$ ) 

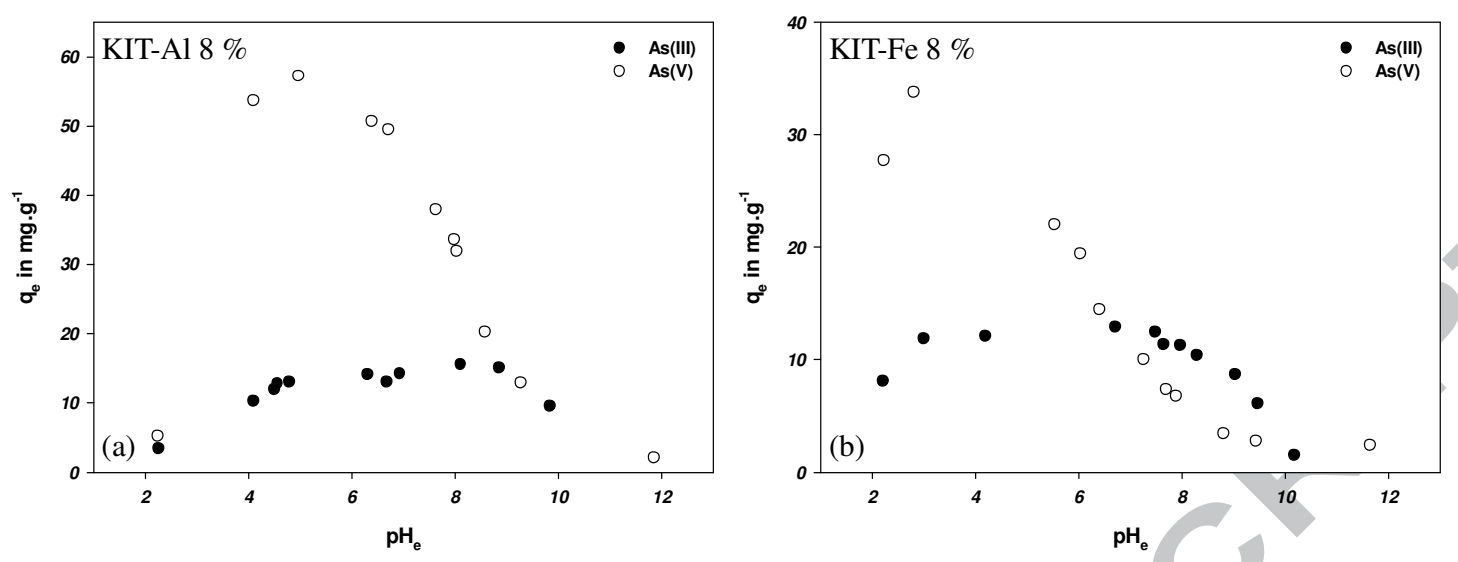

Figure 8 pH effect onto As(III) and As(V) adsorption onto KIT-Al $8 \%$ (a) and KIT-Fe $8 \%$ (b). Starting corresponding arsenic concentration is $55 \mathrm{ppm}$ and adsorbent dosage is 1 g.L $\mathrm{L}^{-1}$
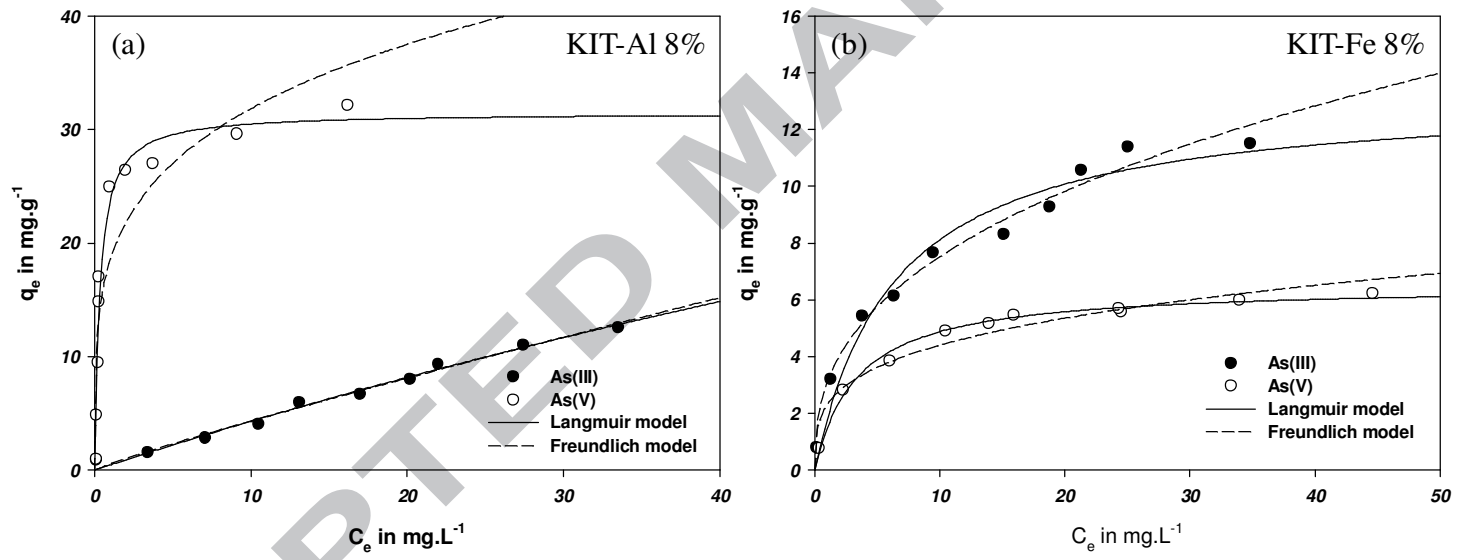

Figure 9 Adsorption isotherms of As(III) and As(V) onto KIT-Fe $8 \%$ (a) and KIT-Al $8 \%$ (b). Equilibrium pH is 8 

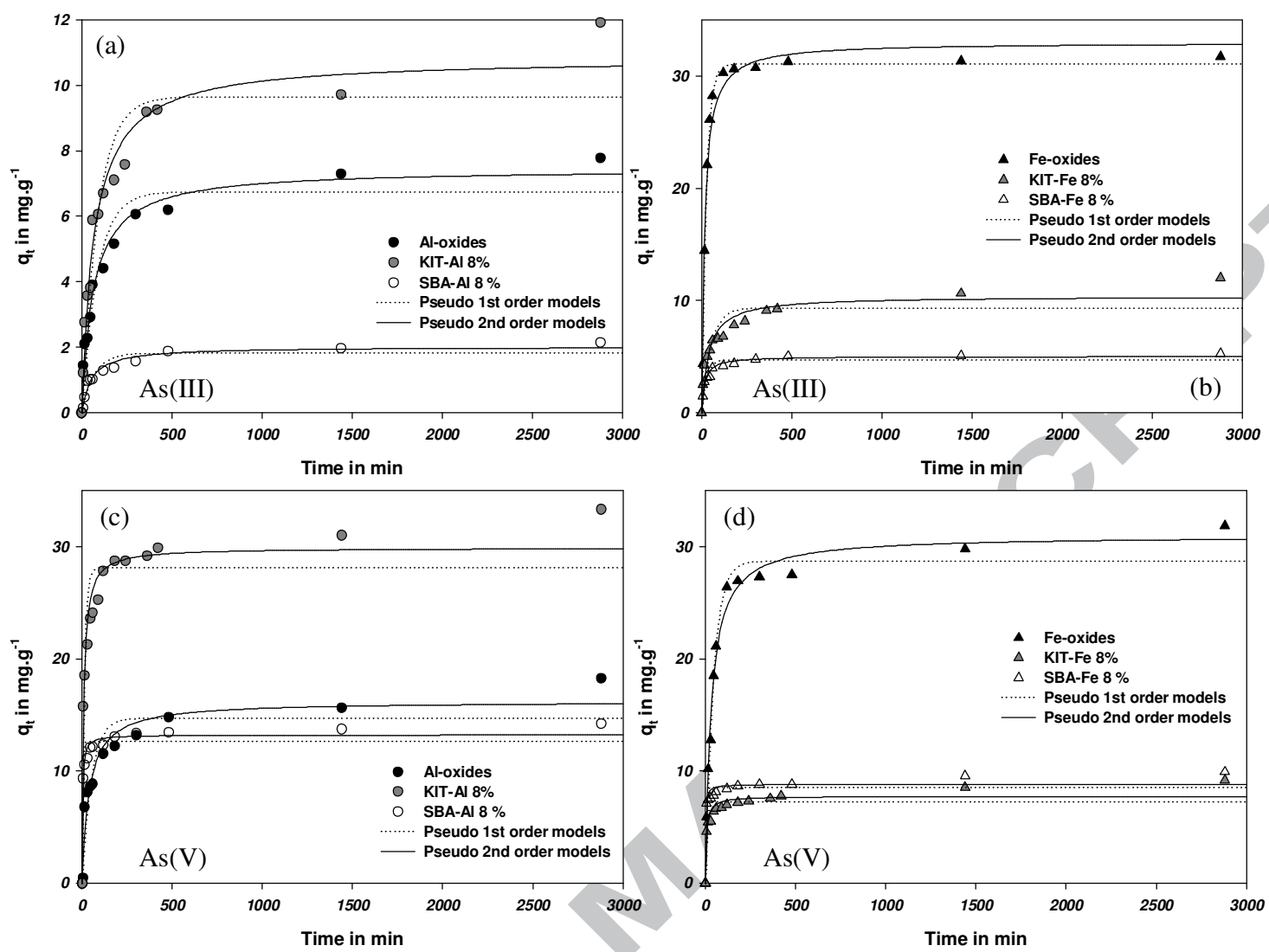

Figure 10 Kinetic experiments using Al and Al coated OMS materials for removing As(III) (a) and As(V) (c) or using

Fe and Fe coated OMS materials in removing As(III) (b) and As(V) (d). Starting concentration is $\sim 50$ ppm 

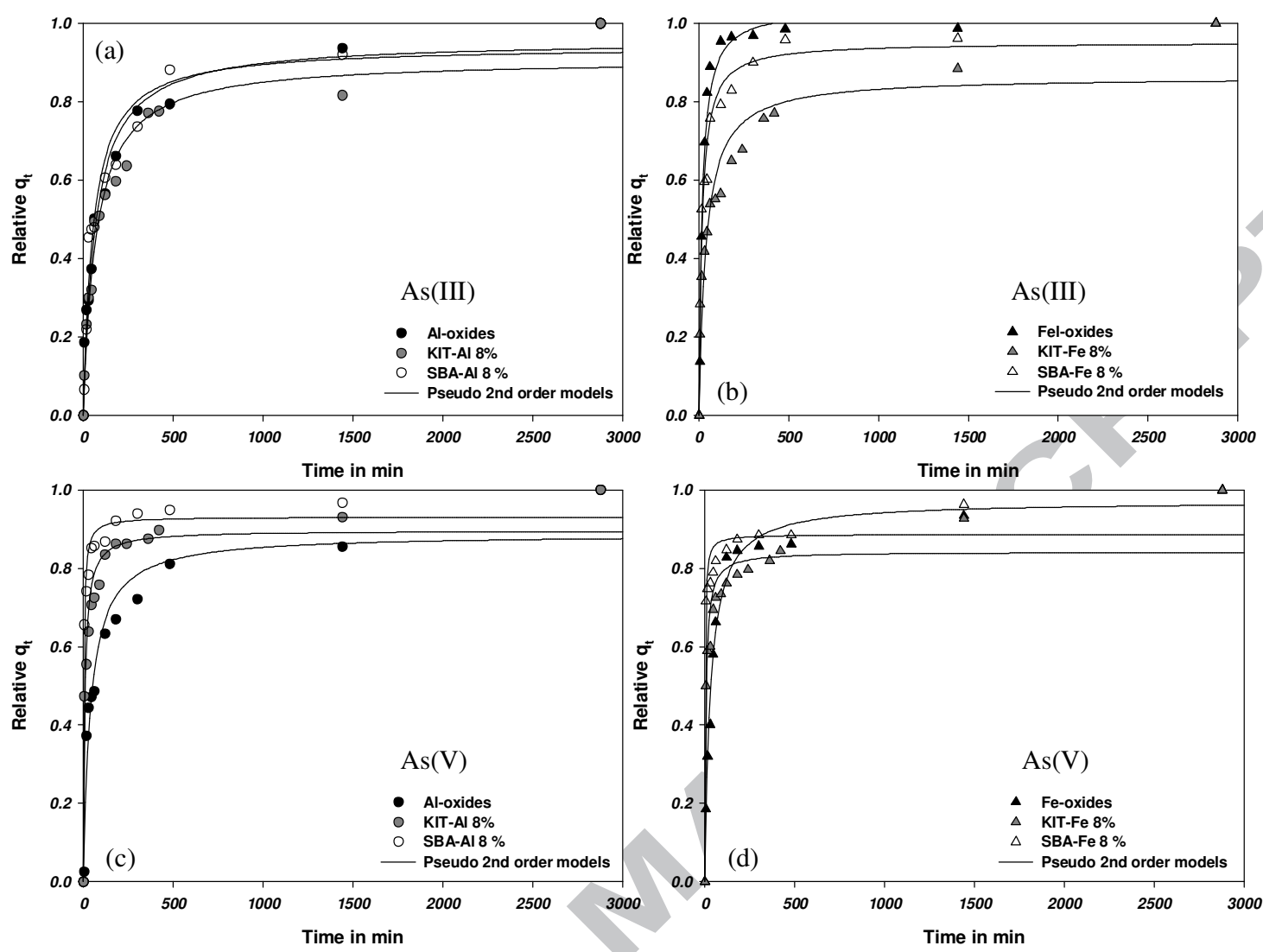

Figure 11 Relative kinetic removal of As(III) by Al and Al coated OMS (a) or Fe and Fe coated OMS (b) or As(V) by $\mathrm{Al}$ and Al coated OMS (c) or Fe and Fe coated OMS (d) 

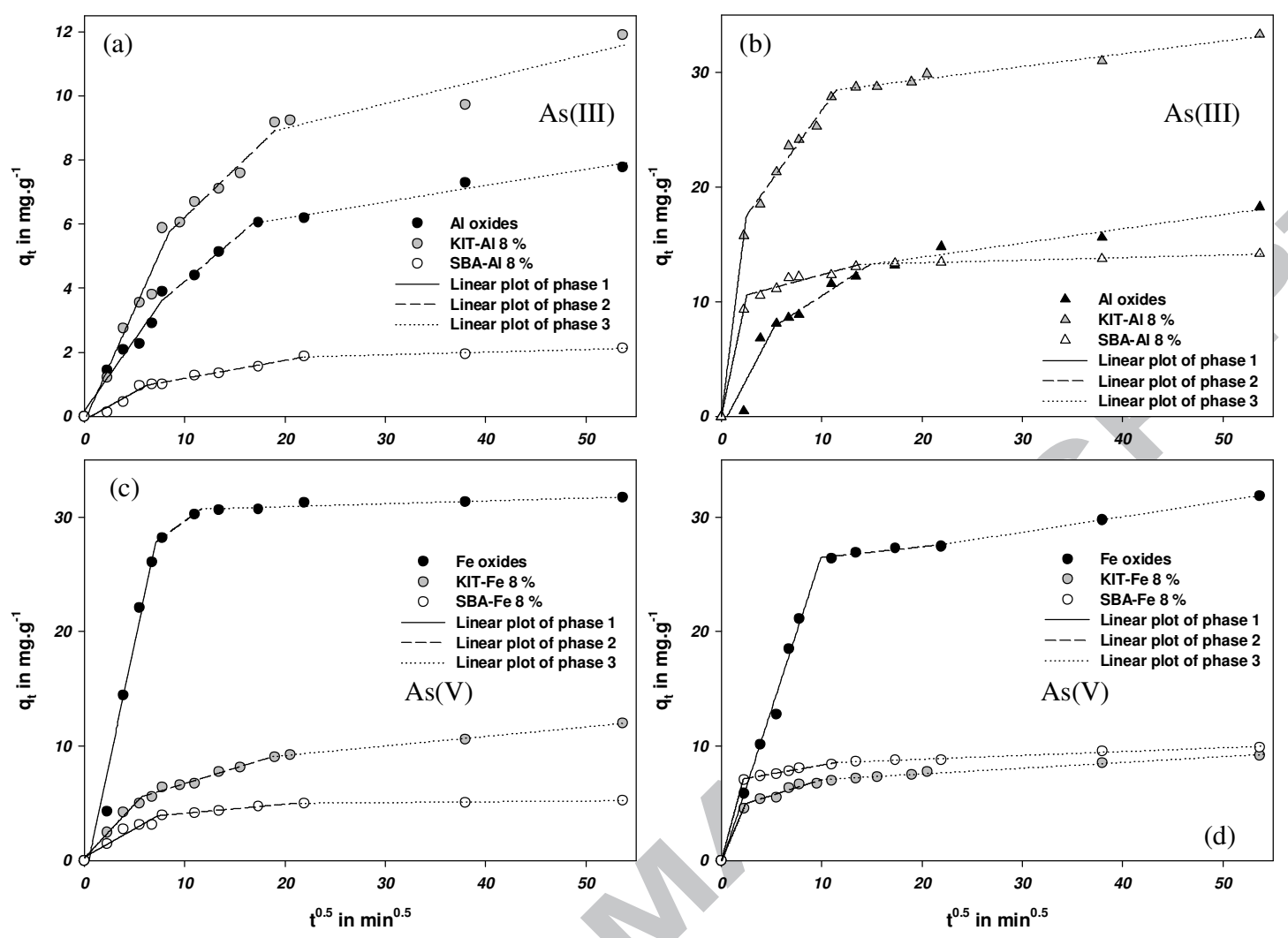

Figure 12 Intraparticle diffusion plot of As(III) (a) and As(V) (b) onto unorganised Al oxides, Al oxides coated 2D and 3D OMS and As(III) (c) and As(V) (d) onto unorganised Fe oxides, Fe oxides coated 2D and 3D OMS 


\section{TABLES}

Table 1 BET analysis results for the Fe oxides coating and Al oxides coating procedures applied to KIT-100 ${ }^{\circ} \mathrm{C}$ materials. These materials were used in the adsorption experiments related to the optimisation of the materials coating

\begin{tabular}{lccccccccc}
\hline & $\begin{array}{c}\text { Fe } \\
\text { loading }\end{array}$ & $\begin{array}{c}\text { Surface } \\
\text { area }\end{array}$ & Porosity & $\begin{array}{c}\text { Average } \\
\text { pore } \\
\text { size }\end{array}$ & & $\begin{array}{c}\text { Al } \\
\text { loading }\end{array}$ & $\begin{array}{c}\text { Surface } \\
\text { area }\end{array}$ & $\begin{array}{c}\text { Average } \\
\text { Porosity } \\
\text { pore } \\
\text { size }\end{array}$ \\
\hline Silica & $\%$ & $\mathrm{~m}^{2} \cdot \mathrm{g}^{-1}$ & ${\mathrm{cc} \cdot \mathrm{g}^{-1}}$ & $\mathrm{~nm}$ & Silica & $\%$ & $\mathrm{~m}^{2} \cdot \mathrm{g}^{-1}$ & ${\mathrm{cc} \cdot \mathrm{g}^{-1}}^{-1}$ & $\mathrm{~nm}$ \\
\hline KIT & 0 & 853.2 & 1.356 & 6.36 & $\mathrm{KIT}$ & 0 & 853.2 & 1.356 & 6.36 \\
KIT & 1 & 607.2 & 0.866 & 5.70 & KIT & 1 & 591.3 & 1.034 & 7.00 \\
KIT & 3 & 530.0 & 0.671 & 5.06 & KIT & 3 & 442.2 & 0.770 & 6.97 \\
KIT & 8 & 520.9 & 0.575 & 4.42 & KIT & 8 & 207.8 & 0.434 & 8.36 \\
KIT & 15 & 267.2 & 0.311 & 4.65 & KIT & 15 & 252.4 & 0.359 & 5.69 \\
KIT & 20 & 271.9 & 0.315 & 4.64 & KIT & 20 & 294.1 & 0.387 & 5.26 \\
KIT & 30 & 222.0 & 0.241 & 4.33 & KIT & 30 & 83.2 & 0.118 & 5.68 \\
\hline
\end{tabular}

Table 2 BET analysis summary of materials used in adsorption experiments

\begin{tabular}{lcccc}
\hline & & Surface area & Porosity & Average pore size \\
\hline Name & Silica & $\mathbf{m}^{\mathbf{2}} \cdot \mathbf{g}^{-\mathbf{1}}$ & $\mathbf{c c . g}^{-\mathbf{1}}$ & $\mathbf{n m}$ \\
\hline KIT-Fe 8 \% & KIT & 520.9 & 0.575 & 4.42 \\
KIT-Al 8\% & KIT & 207.8 & 0.434 & 8.36 \\
SBA-Fe 8 \% & SBA & 643.2 & 0.923 & 6.04 \\
SBA-Al 8\% & SBA & 611.2 & 0.864 & 5.37 \\
Fe oxide & - & 203.2 & 0.231 & 4.54 \\
Al oxide & - & 11.3 & 0.001 & 0.49 \\
\hline
\end{tabular}

Table 3 Adsorption capacity of tailored coated OMS sorbents toward As(III) and As(V)

\begin{tabular}{cccccc}
\hline \multicolumn{2}{c}{ OMS coating content } & \multicolumn{2}{c}{ Relative removal capacity for As } & \multicolumn{2}{c}{ Absolute As removal } \\
\hline Fe oxides & Al oxides & As(III) & $\mathbf{A s}(\mathbf{V})$ & $\mathbf{A s}(\mathbf{I I I})+\mathbf{A s}(\mathbf{V})$ & $\mathbf{A s}(\mathbf{I I I})+\mathbf{A s}(\mathbf{V})$ \\
\hline $\boldsymbol{\%}$ & \% & \% & \% & \% & $\mathbf{m g . g}^{-\mathbf{1}}$ \\
\hline $\mathbf{0}$ & 100 & 16.19 & 83.81 & 100 & 39.29 \\
$\mathbf{1 0}$ & 90 & 17.73 & 82.27 & 100 & 46.09 \\
$\mathbf{2 5}$ & 75 & 20.69 & 79.31 & 100 & 41.90 \\
$\mathbf{5 0}$ & 50 & 33.67 & 66.33 & 100 & 27.32 \\
$\mathbf{7 5}$ & 25 & 48.05 & 51.95 & 100 & 20.81 \\
$\mathbf{9 0}$ & 10 & 61.33 & 38.67 & 100 & 20.17 \\
$\mathbf{1 0 0}$ & 0 & 86.78 & 13.22 & 100 & 11.65 \\
\hline
\end{tabular}

Table 4 Langmuir and Freundlich models constants for As(III) and As(V) adsorption isotherms onto KIT-Fe $8 \%$ and KIT-Al $8 \%$ 


\begin{tabular}{lccccccc}
\hline Adsorbent & As & $\boldsymbol{q}_{\boldsymbol{m}}$ & $\boldsymbol{b}_{\boldsymbol{L}} \times \mathbf{1 0}$ & $\mathbf{r}^{\mathbf{2}}$ & $\boldsymbol{K}_{\boldsymbol{F}}$ & $\boldsymbol{n}$ & $\mathbf{r}^{\mathbf{2}}$ \\
\hline & & $\mathbf{m g . \mathbf { g } ^ { - 1 }}$ & $\mathbf{L . m \mathbf { m } ^ { - 1 }}$ & \multicolumn{4}{c}{$\mathbf{m g}^{\mathbf{1 - n}} \mathbf{. g}^{-\mathbf{1}} \mathbf{L}^{\boldsymbol{n}}$} \\
KIT-Al 8 \% & As(III) & 80.77 & 0.06 & 0.989 & 0.54 & 0.91 & 0.988 \\
KIT-Al 8 \% & As(V) & 31.49 & 30.59 & 0.954 & 18.48 & 0.28 & 0.797 \\
KIT-Fe 8 \% & As(III) & 13.28 & 1.58 & 0.962 & 3.10 & 0.39 & 0.983 \\
KIT-Fe 8 \% & As(V) & 6.52 & 2.97 & 0.989 & 2.30 & 0.28 & 0.942 \\
\hline
\end{tabular}

Table 5 Separation factor and adsorption capacity at 100 ppb using Langmuir model for As(III) and As(V) adsorption isotherms onto KIT-Fe $8 \%$ and KIT-Al $8 \%$

\begin{tabular}{lccc}
\hline Adsorbent & Pollutant & $\mathbf{R}_{\mathbf{L}}-\mathbf{0 . 1}$ & $\mathbf{q}_{\mathrm{e}^{-\mathbf{0 . 1}}}$ \\
\hline KIT-Al 8 \% & & & $\mathbf{m g . g}^{-1}$ \\
KIT-Al 8 \% & As(III) & 0.999 & 0.045 \\
KIT-Fe 8 \% & As(V) & 0.766 & 7.377 \\
KIT-Fe 8 \% & As(III) & 0.984 & 0.206 \\
\hline
\end{tabular}

Table 6 A comparison of the produced materials adsorption capacity with data from the literature. MAA (Mesoporous Activated Alumina), MS (Mesoporous Silica), OMA (Organised Mesoporous Alumina), ZVI (Zero Valent Iron), AC (Activated Carbon)

\begin{tabular}{|c|c|c|c|c|c|c|c|}
\hline \multirow[t]{2}{*}{ Adsorbents } & \multirow{2}{*}{$\begin{array}{l}\text { As } \\
\text { ppm }\end{array}$} & \multicolumn{2}{|c|}{$q m$ in $\mathrm{mg} \cdot g-1$} & \multicolumn{2}{|c|}{$\begin{array}{l}\text { qe-0.1 in mg.g- } \\
1\end{array}$} & \multirow[t]{2}{*}{$\begin{array}{l}\text { Best fit } \\
\text { isotherm }\end{array}$} & \multirow[t]{2}{*}{ Reference } \\
\hline & & $\mathrm{As}(\mathrm{III})$ & $\operatorname{As}(\mathrm{V})$ & $\mathrm{As}(\mathrm{III})$ & $\mathrm{As}(\mathrm{V})$ & & \\
\hline CuO - MAA & $0-1$ & 2.16 & 2.02 & 0.11 & 0.14 & Langmuir & {$[45]$} \\
\hline $\begin{array}{l}\mathrm{Fe}^{3+} \text { and amino functioned } \\
\mathrm{MS}\end{array}$ & $0-200$ & 142.60 & 101.74 & 0.16 & 0.94 & Langmuir & [46] \\
\hline Iron oxide coated sponge & & 3.85 & 4.50 & 0.33 & 0.29 & Langmuir & [47] \\
\hline Fe $10 \%$-MCM-41 & $0-10$ & - & 26.25 & - & 0.72 & Langmuir & {$[18]$} \\
\hline Highly OMA & & - & - & 5.00 & 19.80 & Other & [48] \\
\hline ZVI on AC & $0-2$ & 18.19 & 12.02 & 8.59 & 10.54 & Langmuir & [49] \\
\hline $\mathrm{CeO}_{2}-\mathrm{ZrO}_{2}$ nanospheres & $0.5-60$ & 74.13 & 133.50 & 16.49 & 57.70 & Langmuir & {$[50]$} \\
\hline KIT-Al $8 \%$ & $0-50$ & 80.80 & 31.50 & 0.05 & 7.38 & Langmuir & This study \\
\hline KIT-Fe $8 \%$ & $0-50$ & 13.30 & 30.60 & 0.21 & 0.19 & Langmuir & This study \\
\hline
\end{tabular}


Table 7 Kinetic models parameters for $\mathrm{As}(\mathrm{III})$ and $\mathrm{As}(\mathrm{V})$ removal onto Al/Fe oxides and Al/Fe coated OMS materials obtained at $\mathrm{C}_{0} \sim 50 \mathrm{ppm}$

\begin{tabular}{|c|c|c|c|c|c|c|c|}
\hline & & \multicolumn{4}{|c|}{ Pseudo- $1^{\text {st }}$ order model } & \multicolumn{2}{|c|}{ Pseudo- $2^{\text {nd }}$ order model } \\
\hline \multirow[t]{2}{*}{ Arsenic } & Adsorbents & $q_{e}$ & $k_{1} \times 10^{2}$ & $\mathrm{r}^{2}$ & $q_{e}$ & $k_{2} \times 10^{3}$ & $\mathrm{r}^{2}$ \\
\hline & & mg.g ${ }^{-1}$ & $\min ^{-1}$ & & mg. $\mathrm{g}^{-1}$ & g. $\mathrm{mg}^{-1} \cdot \mathrm{min}^{-1}$ & \\
\hline \multirow{6}{*}{$\operatorname{As}($ III) } & $\mathrm{Al}$ & 6.75 & 1.17 & 0.917 & 7.45 & 2.10 & 0.967 \\
\hline & KIT-Al $8 \%$ & 9.65 & 1.12 & 0.914 & 10.83 & 1.30 & 0.965 \\
\hline & SBA-Al $8 \%$ & 1.82 & 1.48 & 0.913 & 2.01 & 9.50 & 0.969 \\
\hline & $\mathrm{Fe}$ & 31.07 & 4.03 & 0.998 & 32.98 & 1.90 & 0.980 \\
\hline & KIT-Fe $8 \%$ & 9.33 & 1.97 & 0.815 & 10.36 & 2.50 & 0.924 \\
\hline & SBA-Fe $8 \%$ & 4.72 & 3.87 & 0.914 & 5.02 & 12.20 & 0.973 \\
\hline \multirow{6}{*}{$\operatorname{As}(\mathbf{V})$} & $\mathrm{Al}$ & 14.70 & 1.96 & 0.893 & 16.19 & 1.60 & 0.950 \\
\hline & KIT-Al $8 \%$ & 28.12 & 7.67 & 0.853 & 29.88 & 4.00 & 0.945 \\
\hline & SBA-Al $8 \%$ & 12.68 & 23.50 & 0.931 & 13.22 & 26.80 & 0.974 \\
\hline & $\mathrm{Fe}$ & 28.70 & 2.28 & 0.975 & 30.96 & 1.00 & 0.985 \\
\hline & KIT-Fe $8 \%$ & 7.26 & 13.30 & 0.818 & 7.75 & 21.10 & 0.910 \\
\hline & SBA-Fe $8 \%$ & 8.53 & 34.40 & 0.919 & 8.81 & 63.90 & 0.950 \\
\hline
\end{tabular}

Table 8 Intraparticle diffusion coefficients for $\mathrm{As}(\mathrm{III})$ and $\mathrm{As}(\mathrm{V})$ adsorption onto $\mathrm{Al}$ and Fe unorganised oxides and $\mathrm{Al}$ and Fe coated OMS materials

\begin{tabular}{|c|c|c|c|c|}
\hline & & \multicolumn{3}{|c|}{ Intraparticle diffusion coefficients in $\mathrm{mg}^{-\mathrm{g}^{-1}} \cdot \mathrm{min}^{-0.5}$} \\
\hline Materials & Pollutant & $\mathbf{k}_{\mathrm{a} 1} \times \mathbf{1 0}$ & $\mathbf{k}_{\mathrm{a} 2} \times \mathbf{1 0}$ & $\mathbf{k}_{\mathrm{a} 3} \times \mathbf{1 0}$ \\
\hline Al & & 4.45 & 2.65 & 0.51 \\
\hline KIT-Al $8 \%$ & & 6.98 & 3.01 & 0.77 \\
\hline SBA-Al $8 \%$ & $\Delta \mathrm{c}(\mathrm{III}$ & 1.74 & 0.56 & 0.08 \\
\hline & As(III) & 41.61 & 6.38 & 0.25 \\
\hline KIT-Fe $8 \%$ & & 9.41 & 2.67 & 0.83 \\
\hline SBA-Fe $8 \%$ & & 4.94 & 0.79 & 0.07 \\
\hline Al & & 16.64 & 5.65 & 1.24 \\
\hline KIT-Al $8 \%$ & & 70.44 & 12.23 & 1.11 \\
\hline SBA-Al $8 \%$ & & 41.63 & 2.37 & 0.22 \\
\hline $\mathbf{F e}$ & & 26.94 & 0.94 & 1.35 \\
\hline KIT-Fe $8 \%$ & & 20.57 & 2.77 & 0.50 \\
\hline SBA-Fe $8 \%$ & & 32.52 & 1.54 & 0.33 \\
\hline
\end{tabular}

Table 9 Dubinin-Radushkevich isotherm parameters and adsorption energy associated to As removal by adsorption onto KIT-Fe $8 \%$ and KIT-AI $8 \%$

\begin{tabular}{lccrrrr}
\hline Adsorbent & Pollutant & $\mathbf{p H}_{\mathbf{e}}$ & $\boldsymbol{q}_{s}$ & $\boldsymbol{k}_{a d} \times 10^{8}$ & $\mathbf{r}^{\mathbf{2}}$ & $\boldsymbol{E}$ \\
\hline KIT-Fe 8 \% & & & $\mathbf{m g . g}^{-\mathbf{1}}$ & $\mathbf{m o l}^{\mathbf{2} . \mathbf{J}^{-2}}$ & & $\mathbf{J . m o l}^{-\mathbf{1}}$ \\
KIT-Fe 8 \% & As(III) & 8 & 10.33 & 263.00 & 0.817 & 435.81 \\
KIT-Al 8 \% & As(V) & 8 & 5.60 & 104.00 & 0.903 & $\mathbf{6 9 2 . 7 2}$ \\
KIT-Al 8 \% & As(III) & 8 & 12.73 & 2380.00 & 0.920 & 144.95 \\
\hline
\end{tabular}




\section{Highlights:}

- 3D and 2D Organised Mesoporous Silica were efficiently coated with Al to Fe oxides

- $8 \%$ metal oxide loading was the most appropriate content for efficient As removal

- Tailoring of adsorbent for $\mathrm{As}(\mathrm{III})$ or $\mathrm{As}(\mathrm{V})$ was achieved by varying $\mathrm{Al}$ to Fe ratio

- Efficiency of tailored absorbent is highly $\mathrm{pH}$ and concentration dependent

- No superior diffusion into organised materials over unorganised materials was shown 